Inert Electrode Program

\title{
Report on the Source of the Electrochemical Impedance on Cermet Inert Anodes
}

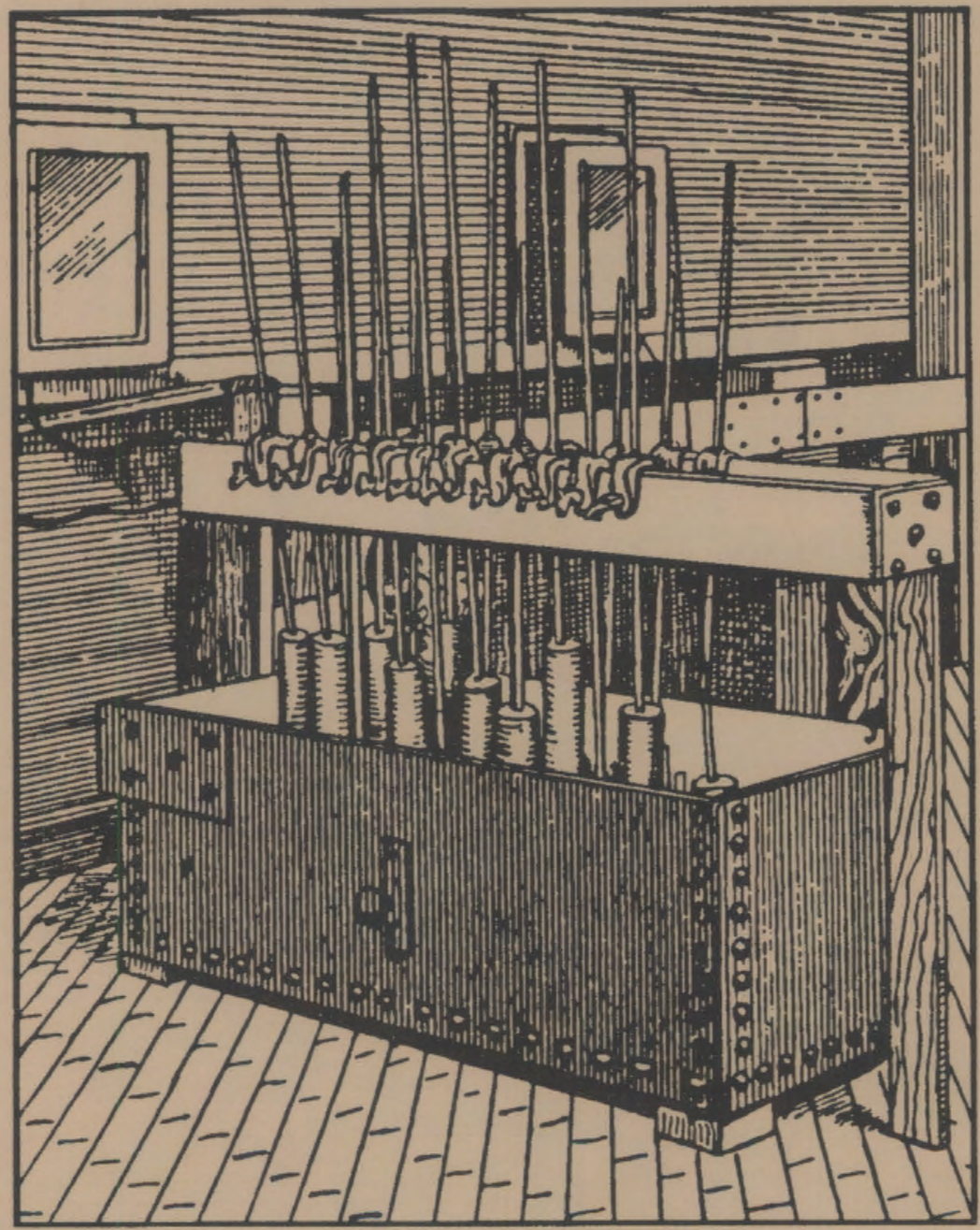

February 1991

Work Supported by the U.S. Department of Energy under Contract DE-AC06-76RLO 1830

Pacific Northwest Laboratory Operated for the U.S. Department of Energy by Battelle Memorial Institute 


\title{
DISCLAIMER
}

This report was prepared as an account of work sponsored by an agency of the United States Government. Neither the United States Government nor any agency thereof, nor Battelle Memorial Institute, nor any of their employees, makes any warranty, expressed or implied, or assumes any legal liability or responsibility for the accuracy, completeness, or usefulness of any information, apparatus, product, or process disclosed, or represents that its use would not infringe privately owned rights. Reference herein to any specific commercial product, process, or service by trade name, trademark, manufacturer, or otherwise does not necessarily constitute or imply its endorsement, recommendation, or favoring by the United States Government or any agency thereof, or Battelle Memorial Institute. The views and opinions of authors expressed herein do not necessarily state or reflect those of the United States Government or any agency thereof.

\author{
PACIFIC NORTHWEST LABORATORY \\ operated by \\ BATTELLE MEMORIAL INSTITUTE \\ for the \\ UNITED STATES DEPARTMENT OF ENERGY \\ under Contract DE-AC06-76RLO 1830
}

\author{
Printed in the United States of America \\ Available to DOE and DOE contractors from the \\ Office of Scientific and Technical Information, P.O. Box 62, Oak Ridge, TN 37831; \\ prices available from (615) 576-8401. FTS 626-8401. \\ Available to the public from the National Technical Information Service, \\ U.S. Department of Commerce, 5285 Port Royal Rd., Springfield, VA 22161.
}

\section{On the cover:}
Aluminum reduction pots at the Pittsburgh Reduction
Company's (Alcoa's) plant in 1889. Adapted from a photograph, courtesy of Alcoa. 
PNL-7629

UC-313

Inert Electrodes Program

REPORT ON THE SOURCE OF THE

ELECTROCHEMICAL IMPEDANCE ON CERMET INERT ANODES

C. F. Windisch, Jr.

N. D. Stice

February 1991

Prepared for

the U.S. Department of Energy

under Contract DE-ACO6-76RLO 1830

Pacific Northwest Laboratory

Richland, Washington 99352 


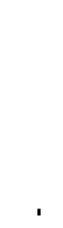




\section{PREFACE}

The Inert Electrode Program at Pacific Northwest Laboratory (PNL) (a) is supported by the Office of Industrial Processes of the U. S. Department of Energy and is aimed at improving the energy efficiency of Hall-Heroult cells through the development of inert anodes. The inert anodes currentiy under study are composed of a cermet material of the general composition NiO$\mathrm{NiFe}_{2} \mathrm{O}_{4}-\mathrm{Cu}$. The program has three primary objectives: (a) to evaluate the anode material in a scaled-up, pilot cell facility, (b) to investigate the mechanisms of the electrochemical reactions at the anode surface, and (c) to develop sensors for monitoring anode and/or electrolyte conditions. This report covers the results of a portion of the studies on anode reaction mechanisms.

(a) PNL is operated for the U.S. Department of Energy by Battelle Memorial Institute under Contract DE-AC06-76RLO I830. 


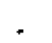




\section{SUMMARY}

The electrochemical impedances of cermet inert anodes in aluminasaturated molten cryolite as a function of frequency, current density, and time indicated that a significant component of the impedance is due to the gas bubbles produced at the anode during electrolysis. The data also showed a connection between surface structure and impedance that appears to be related to the effects of surface structure on bubble flow. Given the results of this work, it is doubtful that a resistive film contributes significantly to the electrochenical impedances on inert anodes. Properties previously assigned to such a film are more likely due to the bubbles and those factors that affect the properties and dynamics of the bubbles at the anode surface. 


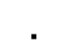




\section{ACKNOWLEDGMENTS}

The authors wish to acknowledge the following staff at the Pacific Northwest Laboratory: N. C. Davis for fabricating the cermet anodes used in this work, Dr. L. G. Morgan for his managerial guidance, and D. L. Schneider for secretarial assistance. We are grateful to Drs. E. W. Dewing and W. E. Haupin for their assistance in our understanding of bubble phenomena. We also acknowledge the programatic support provided by $M$. J. McMonigle and the Office of Industrial Programs, U. S. Department of Energy, Washington, D. C., who provided funding for this work. 


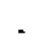




\section{CONTENTS}

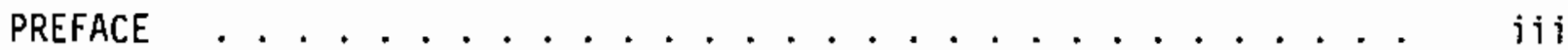

SUMMARY .....................

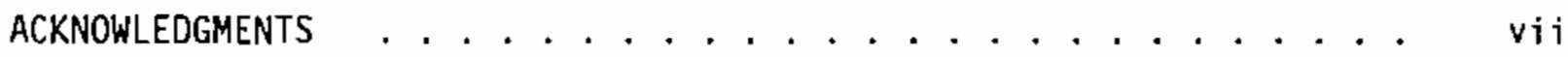

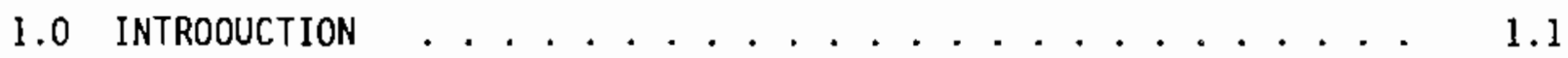

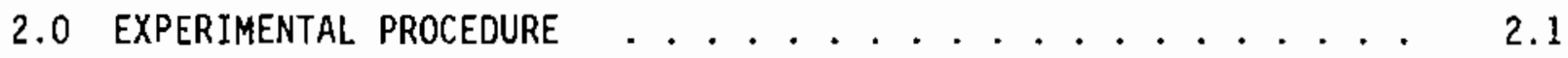

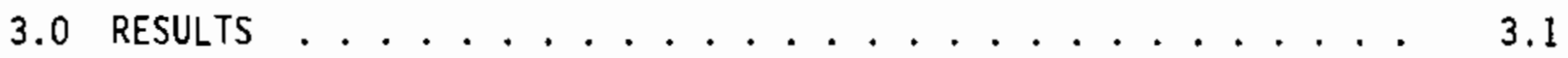

3.1 COMPLEX IMPEDANCE SPECTRA $\ldots \ldots \ldots \ldots . \ldots \ldots$

3.2 VARIATION OF IMPEDANCE HITH CURRENT DENSITY . . . . . 3.3

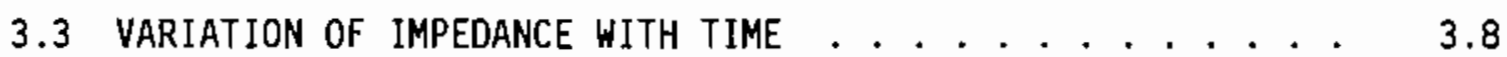

4.0 DISCUSSION . . . . . . . . . . . . . . . . 4.1

4.1 EFFECT OF ANODE CONFIGURATION .............. 4.1

4.2 COMPLEX IMPEDANCE SPECTRA . . . . . . . . . 4.2

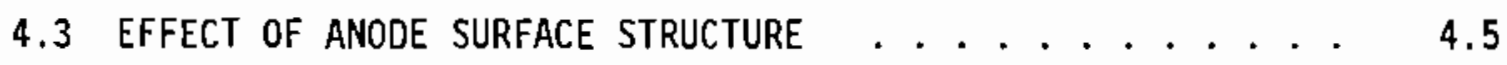

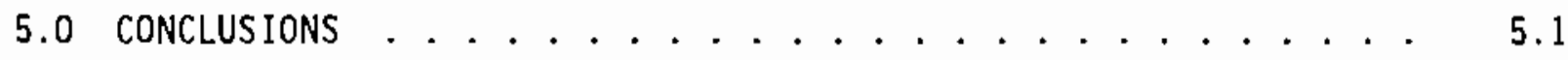

6.0 REFERENCES ............................ 6.1 



\section{FIGURES}

2.1 Apparatus for Electrochemical Impedance Studies . . . . . . . 2.2

2.2 Various Shapes and Configurations of Anodes Tested ..... 2.2

2.3 Schematic of Platinum Brush Anode ........... 2.4

3.1 Electrochemical Impedance Spectra for Fresh Cermet Anode in Alumina-Saturated Molten Cryolite at $983^{\circ} \mathrm{C}$ at (a) $0.44 \mathrm{~A} / \mathrm{cm}^{2}$ and (b) $0.80 \mathrm{~A} / \mathrm{cm}^{2} \ldots \ldots 3.2$

3.2 Electrochemical Impedance Spectra for Platinum Rod Anode in Alumina-Saturated Molten fryolite at $983^{\circ} \mathrm{C}$ at (a) $0.53 \mathrm{~A} / \mathrm{cm}^{2}$ and (b) $1.0 \mathrm{~A} / \mathrm{cm}^{2} \ldots \ldots . . . . . .2$

3.3 Impedance as a Function of Current Density for Fresh Cermet Anode . . . . . . . . . . . . 3.4

3.4 Impedance as a Function of Current Density for Precorroded Cermet Anode . . . . . . . . . . . 3.4

3.5 Impedance as a Function of Current Density for Planar Platinum Anode . . . . . . . . . . . 3.5

3.6 Impedance as a Function of Current Density for Platinum Rod Anode . . . . . . . . . . . 3.5

3.7 Impedance as a Function of Current Density for Platinum Button Anode . . . . . . . . . . 3.6

3.8 Impedance as a Function of Current Density for Platinum Brush Anode . . . . . . . . . . . . 3.6

3.9 Linear Regions of $Z^{\prime}$ Versus Current Density Curves for Platinum Button and Platinum Rod Anodes . . . . . . 3.9

3.10 Linear Regions of $Z^{\prime}$ Versus Current Density Curves for Fresh Cermet and Precorroded Cermet Anodes . . . . . 3.9

3.11 Linear Regions of $Z^{\prime}$ Versus Current Density Curves for Planar Platinum and P1atinum Brush Anodes ...... 3.10

3.12 Variation of $Z^{\prime}$ with Time for Fresh Cermet, Precorroded Cermet and PTatinum Rod Anodes ....... 3.10

4.1 Variation of the Voltage Drop Through the Electrolyte with Current Density for the Fresh Cermet and Platinum Rod Anodes 



\section{TABLES}

2.1 Characteristics of Anodes ............ 2.1

3.1 Estimated $Z^{\prime}$ Intercepts .............. 3.3

4.1 Impedances and Overvoltages for Anodes . . . . . . . 4.2 



\subsection{INTRODUCTION}

Experimental studies conducted at the Pacific Northwest Laboratory (PNL) in FY 1987, FY 1988 and early FY 1989 indicated that the cermet inert anodes evaluated by PNL exhibited a characteristic impedance during the electrolytic production of aluminum in bench-scale Hall-Heroult cells. This impedance was found to have the following characteristics (Strachan et al. 1988):

- It was largely resistive in nature.

- It varied as a function of current density, giving a minimum at about $0.5 \mathrm{~A} / \mathrm{cm}^{2}$.

- It appeared to depend on alumina concentration in the electrolyte. In general, the impedance seemed to increase with increasing alumina concentration.

- It exhibited a time dependence. Different anodes gave different impedances at different times after polarization.

- At high current densities $\left(>1 \mathrm{~A} / \mathrm{cm}^{2}\right)$, discontinuous changes in the impedance occurred, causing "spikes" in the current or voltage data.

Based on these characteristics, PNL originally proposed that a resistive film formed on inert anodes during electrolysis. It was argued that the formation of this film was necessary to protect the inert anode from corrosion reactions that would otherwise occur in the molten electrolyte. It was also proposed that an anodic current density of $0.5 \mathrm{~A} / \mathrm{cm}^{2}$ formed a film with optimum passivating-like characteristics. At lower current densities, the film was proposed to be incompletely formed, resulting in corrosion of the cermet's metallic phase. At higher current densities, it was proposed that the film would become too thick and its resistance would become too high to sustain the current density. Consequently, the film would rupture, resulting in sudden and severe corrosion at the electrode's metal phase. The rupturing events in the film were indicated by sudden drops in impedance and appeared as "spikes" in the voltage data for a cell under galvanostatic (constant current) control.

PNL also proposed that the quality of the film depended on the alumina concentration in the electrolyte. Higher alumina concentrations seemed to 
favor a more resistive, presumably thicker, film. Consequently, film rupturing behavior was considered to be more likely at high alumina concentrations (close to saturation) when current densities were above $0.5 \mathrm{~A} / \mathrm{cm}^{2}$. Problems with reproducibility of the experimental results were encountered, however, when attempts were made to relate anode impedance explicitly to alumina concentration. It was then concluded that the film impedance was dynamic, changing with time and with small fluctuations in cell conditions.

Attempts to identify the composition of the film in FY 1988 were largely unsuccessful. Post-mortem $X$-ray diffraction of frozen electrolyte near the surface region showed the presence of alumina, but it was uncertain whether the alumina was part of a film or simply precipitate that formed on the anode during cool-down.

During FY 1989 and FY 1990, experiments were performed to identify the properties and composition of the film using a variety of techniques. The milestone report titled "Characterization of the Reaction Layer or Film on PNL Inert Anodes: Progress Report for April-December 1989" (Windisch and Stice 1990a) discussed the results of electrochemical impedance and potential-step studies. These results suggested that morphological characteristics of the cermet anode, specifically roughness and surface porosity, play an important role in reactions at the surface and in determining electrode impedance. These conclusions were supported by the results of microscopic and compositional analysis of the reaction zone reported in the follow-up milestone document titled "Final Report on the Characterization of the $F i 1 \mathrm{~m}$ on Inert Anodes" (Windisch and Stice 1990b). This work indicated that an alumina film does not form to protect the cermet inert anode from dissolution. Rather, significant morphological and compositional changes occurred at or near the anode surface during polarization. These changes and the chemical changes that caused them involve the cermet material itself and appear to be responsible for some of the properties previously assigned to an alumina film.

Since the electrochemical impedance measured on the cermet inert anodes was originally attributed by PNL to the alumina film (Strachan et al. 1988), another explanation for the source of the impedance was required. The objective of the current work was to obtain more electrochemical impedance 
data under a variety of conditions and on different anodes to see if any relationships could be developed among experimental parameters that might clarify the source of the anode impedance. The results of these tests, when compared with studies reported in the 1iterature (Tobias 1959; Dewing and van der Kouwe 1975; Zuca et a). 1980) and taken together with the recent work at PNL (Windisch and Stice 1990a,b), strongly suggest that the oxygen gas bubbles produced during electrolysis provide an important contribution to the electrochemical impedance at the anode. The impedance was also found to depend strongly on anode surface structure and on cell geometry. However, these latter two effects are not completely independent of the bubble phenomena. (a) Consequent1y, it was difficult to separate out their contribution in these studies.

A number of different types of anodes were examined to study the effects of surface structure on electrochemical impedance. Cermet inert anodes freshly fabricated using procedures reported earlier (Strachan et al. 1988) were the focus of the work. These inert anodes were considered representative of the type currently being deployed in larger cells (Strachan et al. 1990) and were compared with the behavior of the other electrodes. Precorroded cermet inert anodes that had a rough and highly porous surface layer were tested to determine if a highly porous surface structure influenced the impedance in any way. Platinum anodes with four different configurations were tested for comparison with the cermet anodes. Different configurations were employed to address problems associated with changes in cell constant with anode size. Also, comparing effects on horizontal and flat orientations helped determine the source of the anode impedance. "Platinum brush" anodes were fabricated and studied to simulate inert anodes with controlled and constant porosity. Similar brush electrodes have been used to determine the effect of surface structure on electrochemical impedance in other systems (de Levie 1964). The relationship between the behavior of planar platinum and

(a) For example, a rough surface will have more hindered bubble flow than a smooth surface. While the roughness itself may contribute to the impedance (perhaps as an area correction), its effect is difficult to distinguish from that of the change in gas flow dynamics that accompanies roughening. This topic is discussed further in Section 4.3 . 
platinum brush anodes was compared with that between fresh cermet and precorroded cermet anodes to help interpret the role of anode surface structure. 


\subsection{EXPERIMENTAL PROCEDURE}

Experiments were performed using the bench-scale experimental setup shown in Figure 2.1. The electrochemical cell used a three-electrode arrangement including the anode under study as the working electrode, the graphite crucible as the counter electrode, and a reference electrode. The anodes studied included fresh cermet anodes, precorroded cermet anodes, and platinum anodes with various configurations. As shown in Figure 2.2, the configuration for the cermet anodes was a small cylinder with one face exposed to the electrolyte. Four configurations for platinum anodes were evaluated and these are discussed below. A summary of the important characteristics and dimensions of the anodes tested in this study is given in Table 2.1.

The fresh cermet inert anodes were fabricated at PNL (from $\mathrm{NiO} / \mathrm{NiFe}_{2} \mathrm{O}_{4}$. oxide powder to contain $17 \%$ Cu metal by weight) according to procedures discussed in a previous report (Strachan et al. 1988). They were formed into the shape of a small cylinders with a diameter of $1.03 \mathrm{~cm}$. A boron nitride (BN) sheath was used to protect the walls of the anode, allowing only one of its circular faces with an area of $0.84 \mathrm{~cm}^{2}$ to be exposed to the electrolyte. The face was sanded to a final finish with $\mathrm{SiC}$ paper. The connector bar was a $\mathrm{Ni}$ rod that had been brazed to the anode during the fabrication procedure as discussed in previous reports (Strachan et al. 1988).

\section{TABLE 2.1. Characteristics of Anodes}

\begin{tabular}{llll}
\multicolumn{1}{c}{ Anode } & \multicolumn{1}{c}{ Description of Shape } & Area, $\mathrm{cm}^{2}$ \\
\cline { 1 - 1 } Fresh Cermet & & Cylinder with one face exposed. & 0.84 \\
Precorroded Cermet & Cylinder with one face exposed. & 0.84 \\
Planar Platinum & Rod with one face exposed. & 0.077 \\
Platinum Rod & Cylinder with face and sidewalls exposed. & 1.00 \\
Platinum Button & "Flat" cylinder with one face exposed. & 0.69 \\
Platinum Brush & Bundle of wires with faces exposed. (a) & 0.077
\end{tabular}

(a) This is the macroscopic surface area including the spaces between the wires or the simulated pores. The sum of the areas, of the faces of the individual wires, excluding the pores, was $0.062 \mathrm{~cm}^{2}$. 
1268 Interface

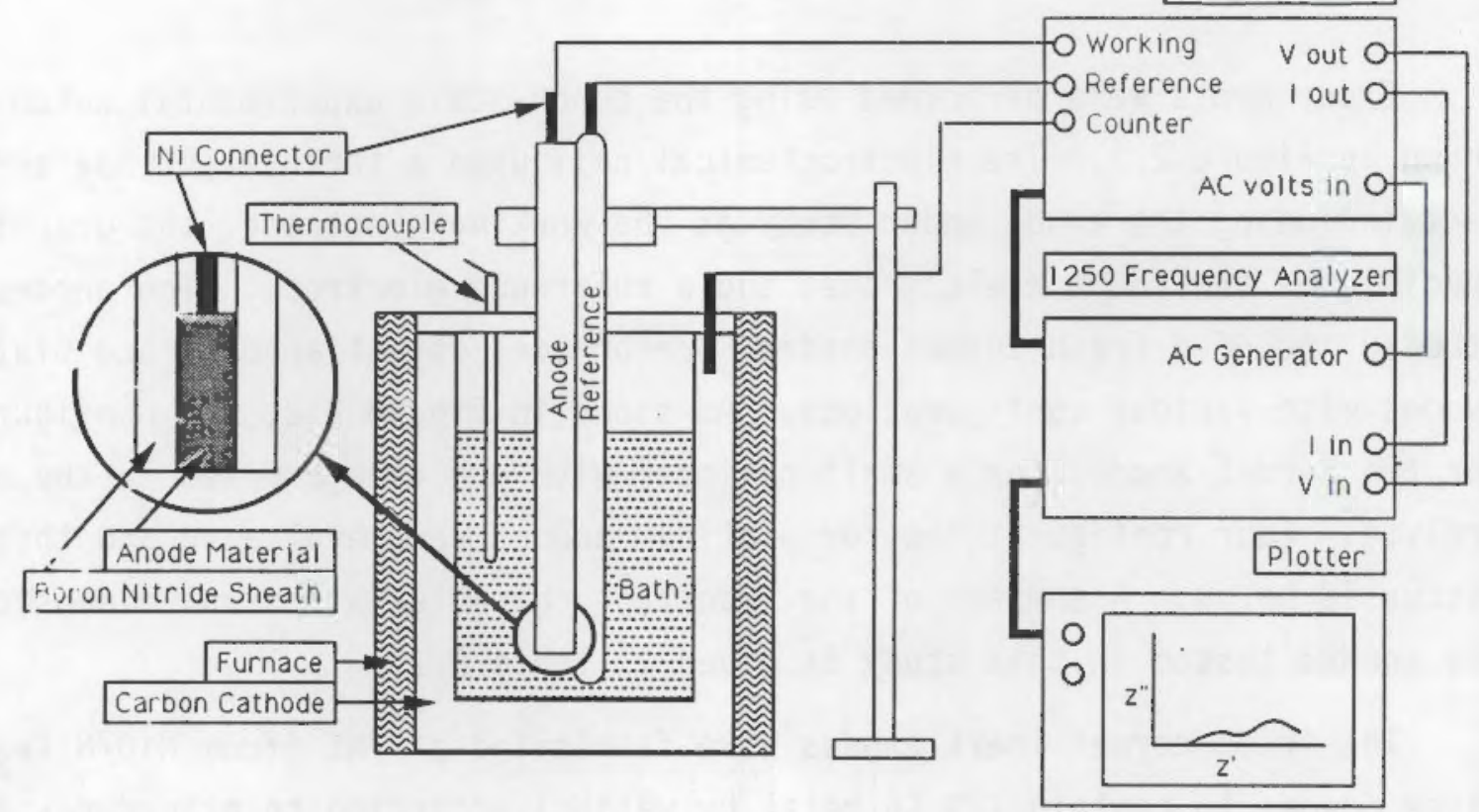

FIGURE 2.1. Apparatus for Electrochemical Impedance Studies. Exploded view of electrode is shown.

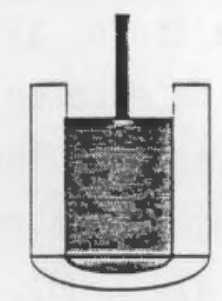

fresh Cermet Precorroded Cermet

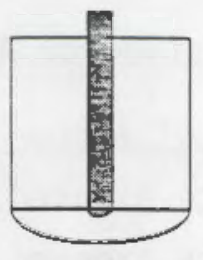

Planar Platinum

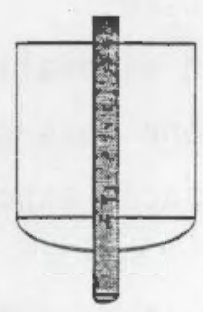

Platinum Rod

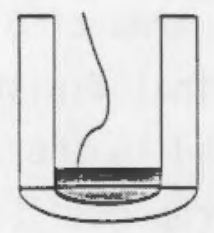

Platinum Button

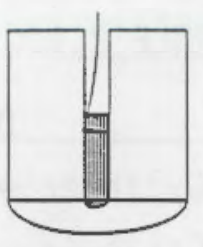

Platinum Brust

FIGURE 2.2. Various Shapes and Configurations of Anodes Tested 
Precorroded cermet inert anodes were prepared and mounted exactly the same as the fresh cermet anodes but, before testing in this work, were polarized anodically for $1 \mathrm{~h}$ at $1 \mathrm{~A} / \mathrm{cm}^{2}$ in a cryolitic bath containing no dissolved alumina. Post-mortem analyses of some of these anodes revealed a $>100 \mu \mathrm{m}$ thick region at the surface that was depleted in copper metal and also very porous.

Platinum anodes with four different configurations were tested. The planar platinum anode was prepared from a $0.312-\mathrm{cm}$-diameter rod obtained from Johnson Matthey, Inc., (a) and mounted with its terminal face flush with the end of the BN sheath. The platinum rod anode was prepared similar to the planar platinum anode and from the same rod stock except that enough circumferential sidewall was left exposed to give a total surface area of $1 \mathrm{~cm}^{2}$. The platinum button anode was prepared from a flat button of platinum with a diameter of $0.94 \mathrm{~cm}$. One side of the button was mounted flush with the BN sheath to give an exposed surface area of $0.69 \mathrm{~cm}^{2}$. All of the platinum anodes were finished in the same way as the fresh cermet anode, i.e., sanded with 600-grit SiC paper. The platinum brush anode was prepared to simulate a surface with a controlled and constant porosity. As shown in Figure 2.3, it consisted of a bundle of 34 wires or bristles each with a diameter of $0.048 \mathrm{~cm}$. The bundle was sheathed in $\mathrm{BN}$, and the exposed surface had the same overall dimensions and appearance as the planar platinum anode except for the open space or simulated pores between the platinum wires.

The cathode or counter electrode used in the experiments was a graphite crucible that also served as the cell container. The crucible was large enough to hold about $1 \mathrm{~kg}$ of electrolyte. No aluminum metal seed was used in these tests. The reference electrode was the $\mathrm{Al} / \mathrm{Al}_{2} \mathrm{O}_{3}$ type, fabricated according to a recently published design (Burgman, Leistra, and Sides 19B6). The reference electrode was placed at approximately the same position relative to the anode for each test to minimize the effect of differences in cell

(a) Johnson Matthey, Inc., Aesar Group, P.0. Box 1087, Seabrook, New Hampshire. 


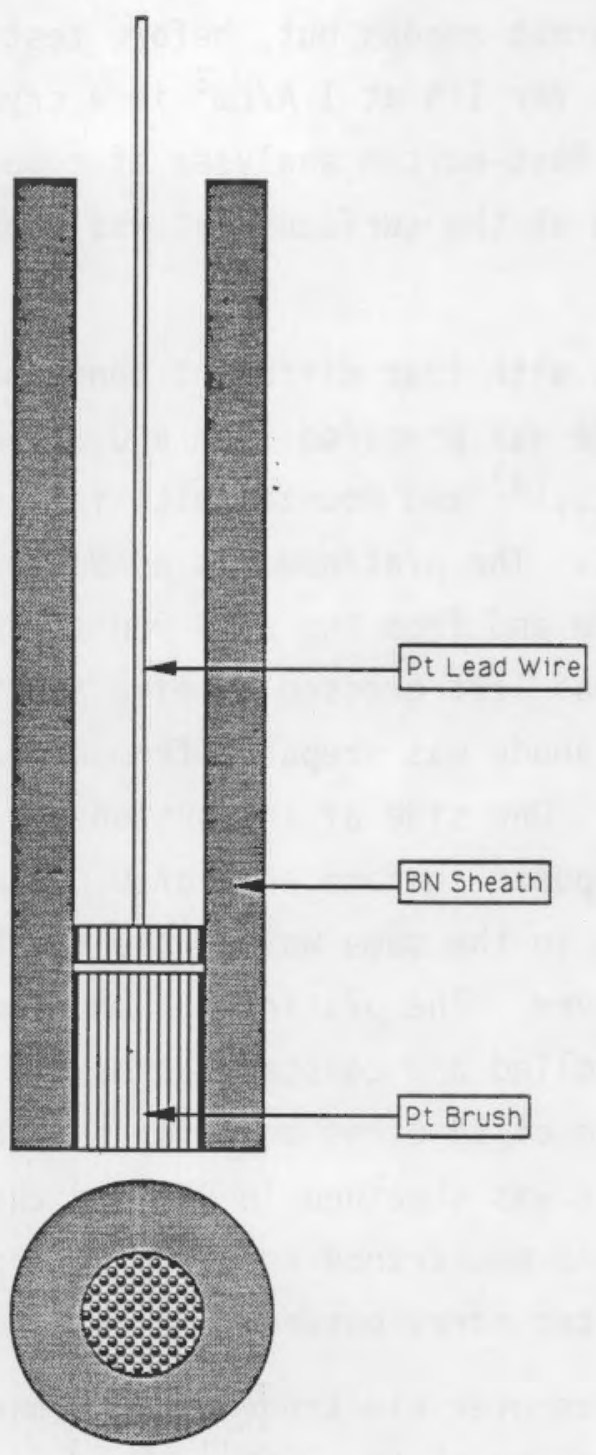

\section{FIGURE 2.3. Schematic of Platinum Brush Anode}

geometry on measured anode impedances. The reference electrode was positioned adjacent to the $B N$ sheath and extended about $1 / 2$ in. below the cylindrical face of the anode.

The electrolyte was prepared by mixing appropriate amounts of reagentgrade materials to give a bath ratio equal to $1.15,5.5 \%$ (by weight) $\mathrm{CaF}_{2}$, $1.0 \% \mathrm{MgF}_{2}$, and $8.0 \%$ alumina (saturation). A temperature controller/furnace/ thermocouple arrangement was used to melt the raw materials to form a "bath" 
and control its temperature at $983^{ \pm} 2^{\circ} \mathrm{C}$. The bath ratio was considered constant and equal to the formulation value (1.15) throughout these shortterm tests. The actual variation of bath ratio has been shown to be negligible over the 6-h working life of a laboratory cell (Windisch and Stice 1990b).

Electrochemical impedances were measured at various current densities using a Solartron 1286 Electrochemical Interface and Solartron 1250 Frequency Response Analyzer (FRA). (a) $A{ }^{ \pm} 10 \mathrm{mV}$ excitation signal was provided by the FRA and superimposed on the controlling voltage. Three types of electrochemical impedance experiments were performed. In the first type, the frequency of the excitation signal was scanned from $0.1 \mathrm{~Hz}$ to $10 \mathrm{kHz}$ using 20 steps per frequency decade. Complex impedance spectra (or plots of the real versus imaginary parts of the complex impedance) were then obtained. These experiments were performed on the fresh cermet inert anodes and on platinum rod anodes. In the second type of experiment, the impedance at $10 \mathrm{kHz}$ was measured for all of the anodes in Table 2.1 as a function of current density (and applied anode potential). The anode potential was set, then the current density and impedance were measured after about $10 \mathrm{~min}$ of equilibration. Data were taken during both a stepwise increase and decrease in potential. In the third type of test, the impedance at $10 \mathrm{kHz}$ was measured as a function of time over a 6-h period after applying a potential which gave a current density of 1 $\mathrm{A} / \mathrm{cm}^{2}$. The current density was kept at this value by carefully adjusting the potential throughout the test.

Data at $10 \mathrm{kHz}$ were collected to determine the behavior of the electrolyte (or purely resistive component of) impedance only. As shown in Section 3.2 , at $10 \mathrm{kHz}$ the contribution of capacitive effects is negligible, particularly at current densities above $0.5 \mathrm{~A} / \mathrm{cm}^{2}$.

(a) Solartron is a tradename of Solartron Instruments, Farmborough, Hampshire, Engl and. 



\subsection{RESULTS}

The impedance data collected in this work included complex impedance spectra, impedance as a function of current density, and impedance as a function of time after applying the controlling voltage.

\subsection{COMPLEX IMPEDANCE SPECTRA}

The complex impedance spectra(a) for the fresh cermet inert anode at current densities of $0.44 \mathrm{~A} / \mathrm{cm}^{2}$ and $0.80 \mathrm{~A} / \mathrm{cm}^{2}$ are shown in Figures $3.1 \mathrm{a}$ and $b$, respectively. Plots for the platinum rod anode at current densities of $0.53 \mathrm{~A} / \mathrm{cm}^{2}$ and $1.0 \mathrm{~A} / \mathrm{cm}^{2}$ are shown in Figures $3.2 \mathrm{a}$ and $\mathrm{b}$, respectively.

The spectra are very similar. Each plot exhibits a loop at low frequencies with a characteristic frequency of about $1 \mathrm{~Hz}$. The diameters of these loops appear to increase with increasing current density, from about $0.07 \mathrm{ohm} \mathrm{cm} \mathrm{cm}^{2}$ at $0.44 \mathrm{~A} / \mathrm{cm}^{2}$ to $0.10 \mathrm{ohm} \mathrm{cm}^{2}$ at $0.80 \mathrm{~A} / \mathrm{cm}^{2}$ in the case of the cermet anode, and from approximately $0.10 \mathrm{ohm} \mathrm{cm}^{2}$ at $0.53 \mathrm{~A} / \mathrm{cm}^{2}$ to $0.15 \mathrm{ohm}$ $\mathrm{cm}^{2}$ at $1.0 \mathrm{~A} / \mathrm{cm}^{2}$ in the case of the platinum rod anode.

The plots also show some features at higher frequencies $(>10 \mathrm{~Hz})$. The high-frequency features were very small and difficult to resolve; however, they are clearer at the lower current density than at the higher current density for both the cermet anode and the platinum rod anode. At the lower current densities they appear to be semicircular. At the higher current densities, the high-frequency features are smaller and obscured (completely, in the case of platinum) by the low-frequency loops.

The high-frequency and low-frequency $Z^{\prime}$-intercepts, given by $Z^{\prime}{ }_{h f}$ and $Z^{\prime}{ }_{1 f}$, respectively, were estimated by extrapolation from Figures 3.1 and 3.2

(a) Complex impedance spectra are plots of the relationship between the real $\left(Z^{\prime}\right)$ and imaginary $\left(-Z^{\prime \prime}\right)$ parts of the complex impedance as a function of the frequency of the excitation signal. These spectra are useful in identifying and characterizing the steps in an electrochemical reaction mechanism. See, for example, Bard and Faulkner (1980). 

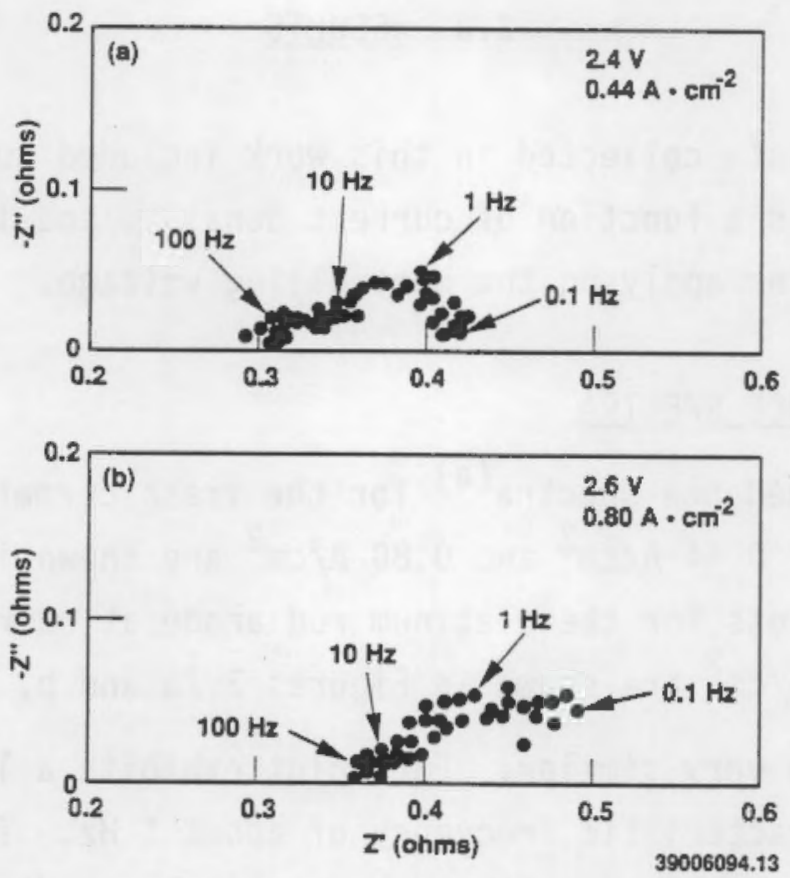

FIGURE 3.1. Electrochemical Impedance Spectra for Fresh Cermet Anode in Alumina-Saturated Molten Cryolite at $983^{\circ} \mathrm{C}$ at

(a) $0.44 \mathrm{~A} / \mathrm{cm}^{2}$ and (b) $0.80 \mathrm{~A} / \mathrm{cm}^{2}$
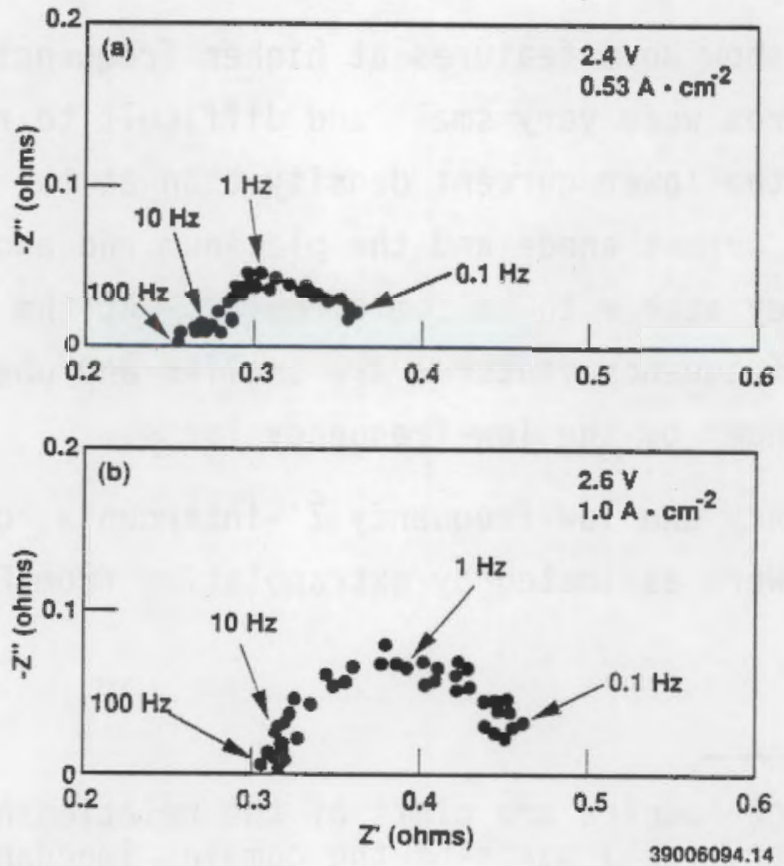

FIGURE 3.2. Electrochemical Impedance Spectra for Platinum Rod Anode in Alumina-Saturated Molten Cryglite at $983^{\circ} \mathrm{C}$ at

(a) $0.53 \mathrm{~A} / \mathrm{cm}^{2}$ and (b) $1.0 \mathrm{~A} / \mathrm{cm}^{2}$ 
and are 1isted in Table 3.1. As shown in Table 3.1, $Z^{\prime}$ hf and $Z^{\prime}{ }_{1 f}$ increase with increasing current density for both anodes.

\subsection{VARIATION OF IMPEDANCE WITH CURRENT DENSITY}

The variation of the real $\left(Z^{\prime}\right)$ and imaginary (- $\left.Z^{\prime \prime}\right)$ parts of the complex electrochemical impedance measured at $10 \mathrm{kHz}$ with respect to current density is shown in Figures 3.3 through 3.8 for the six anodes. Data are given for both forward and reverse sweeps in all cases.

As shown in the figures, $Z^{\prime}$ is the predominant component of the complex impedance at $10 \mathrm{kHz}$ and the only significant component at current densities near $0.5 \mathrm{~A} / \mathrm{cm}^{2}$ and above. Since $10 \mathrm{kHz}$ is a "reasonably high" frequency according to the complex impedance spectra in Figures 3.1 and $3.2, Z^{\prime}$ at 10 $\mathrm{kHz}$ can be equated to $\mathrm{Z}^{\prime}{ }_{\mathrm{hf}}$ defined in Section 3.1. Near $0.5 \mathrm{~A} / \mathrm{cm}^{2}$ and above, the impedance is largely resistive. At lower current densities, particularly in the case of the platinum anodes, significant contribution from the imaginary or capacitive component, $-\mathrm{Zn}$, occurs even at $10 \mathrm{kHz}$. This may indicate the presence of some stray reactions, possibly the oxidation of carbon particles from the graphite crucible that occur significantly only at low overpotentials.

The variation of $Z^{\prime}$ with current density followed the same pattern for all of the anodes tested. Under conditions where $-Z^{\prime \prime}$ is negligible, $Z^{\prime}$ increased with increasing current density. This trend has been observed in previous studies at PNL (Strachan et al. 1988).

\section{TABLE 3.1. Estimated $Z^{\prime}$ Intercepts}

\begin{tabular}{|c|c|c|c|}
\hline Anode & $\begin{array}{c}\text { Current Density, } \\
\mathrm{A} / \mathrm{cm}^{2} \\
\end{array}$ & $\begin{array}{c}Z_{h f}^{\prime}, \\
\underline{o h m ~} \mathrm{~cm}^{2}\end{array}$ & $\begin{array}{l}\mathrm{Z}^{\prime}{ }_{1 \mathrm{f}}, \\
\underline{\mathrm{ohm} \mathrm{cm}^{2}}\end{array}$ \\
\hline \multirow[t]{2}{*}{ Fresh Cermet } & 0.44 & 0.30 & 0.42 \\
\hline & 0.80 & 0.36 & 0.50 \\
\hline \multirow[t]{2}{*}{ Platinum Rod } & 0.53 & 0.25 & 0.37 \\
\hline & 1.0 & 0.31 & 0.46 \\
\hline
\end{tabular}




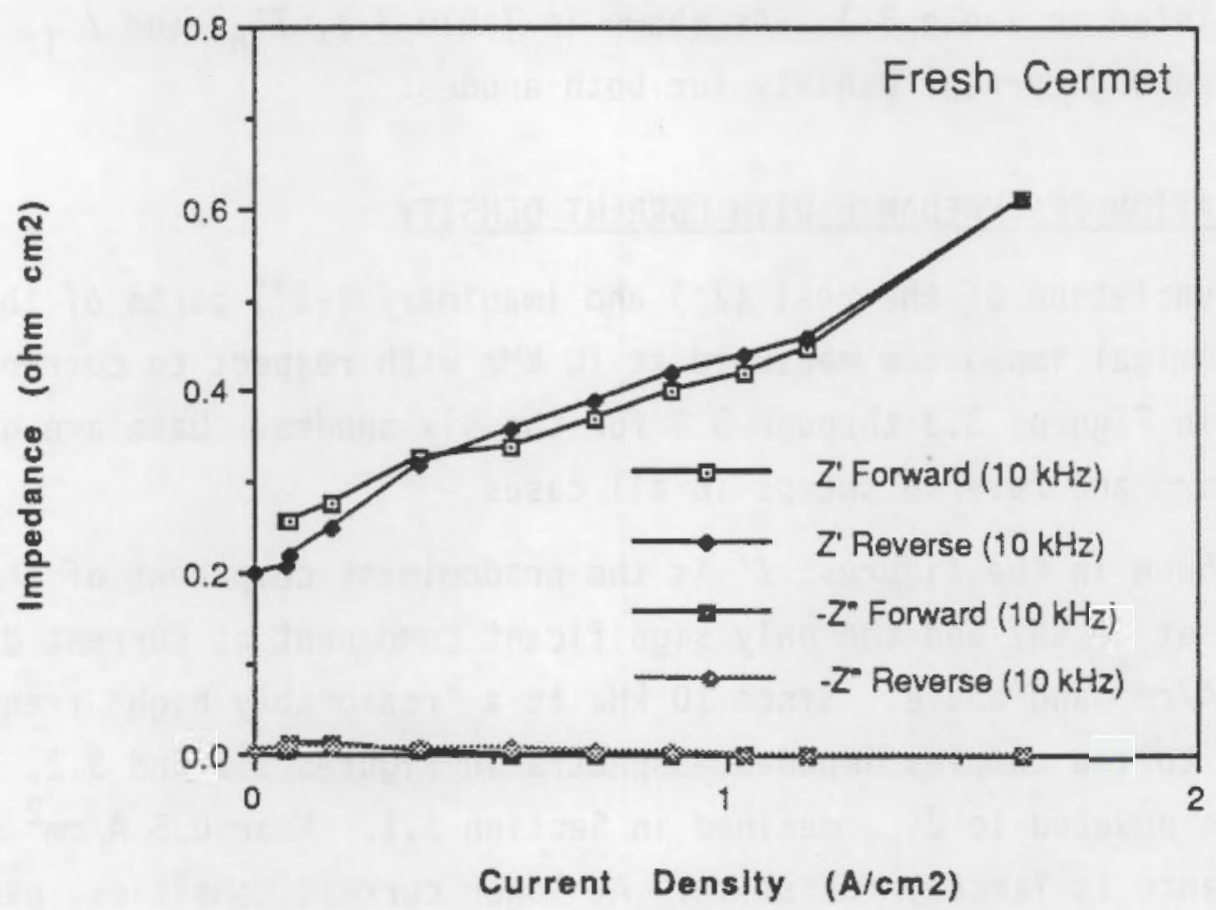

FIGURE 3.3. Impedance as a Function of Current Density for Fresh Cermet Anode

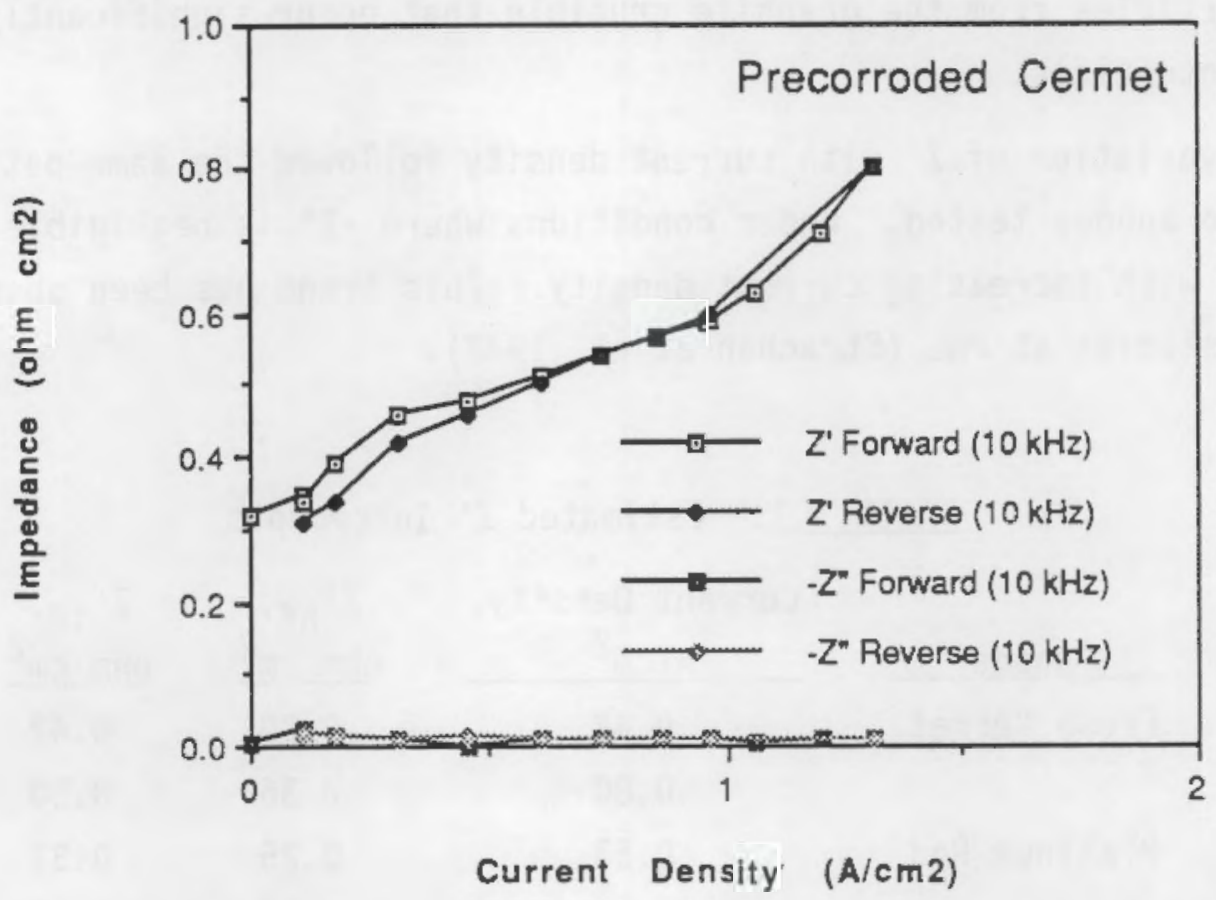

FIGURE 3.4. Impedance as a Function of Current Density for Precorroded Cermet Anode 


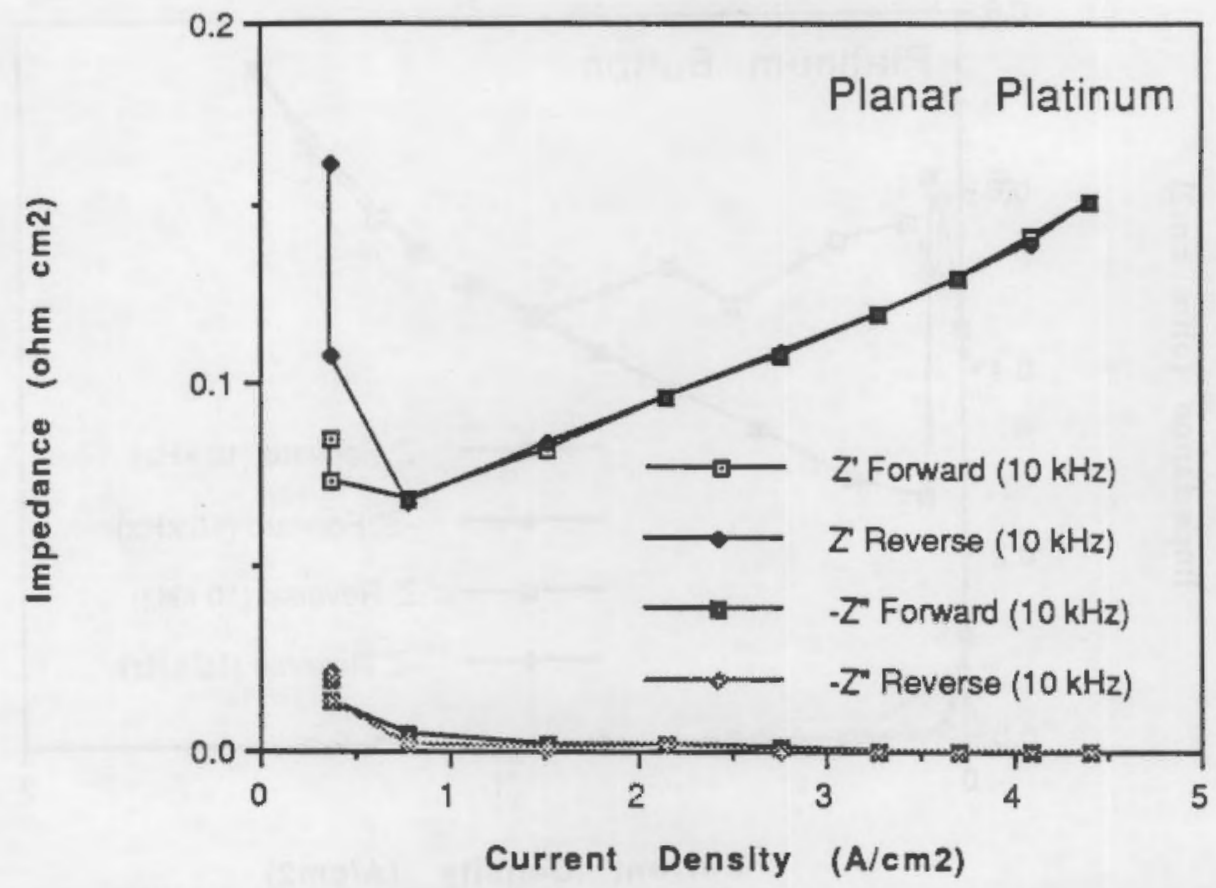

FIGURE 3.5. Impedance as a Function of Current Density for Planar Platinum Anode

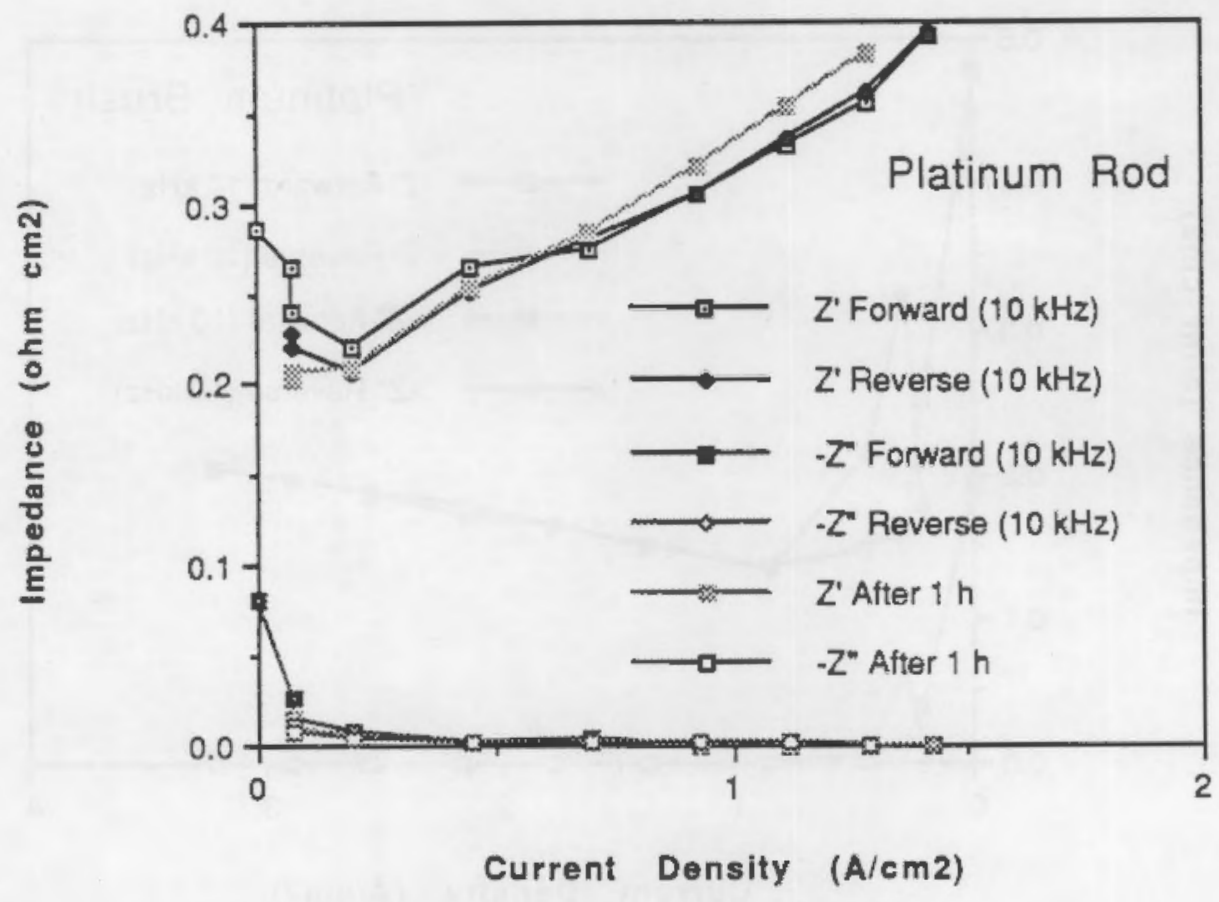

FIGURE 3.6. Impedance as a Function of Current Density for Platinum Rod Anode 


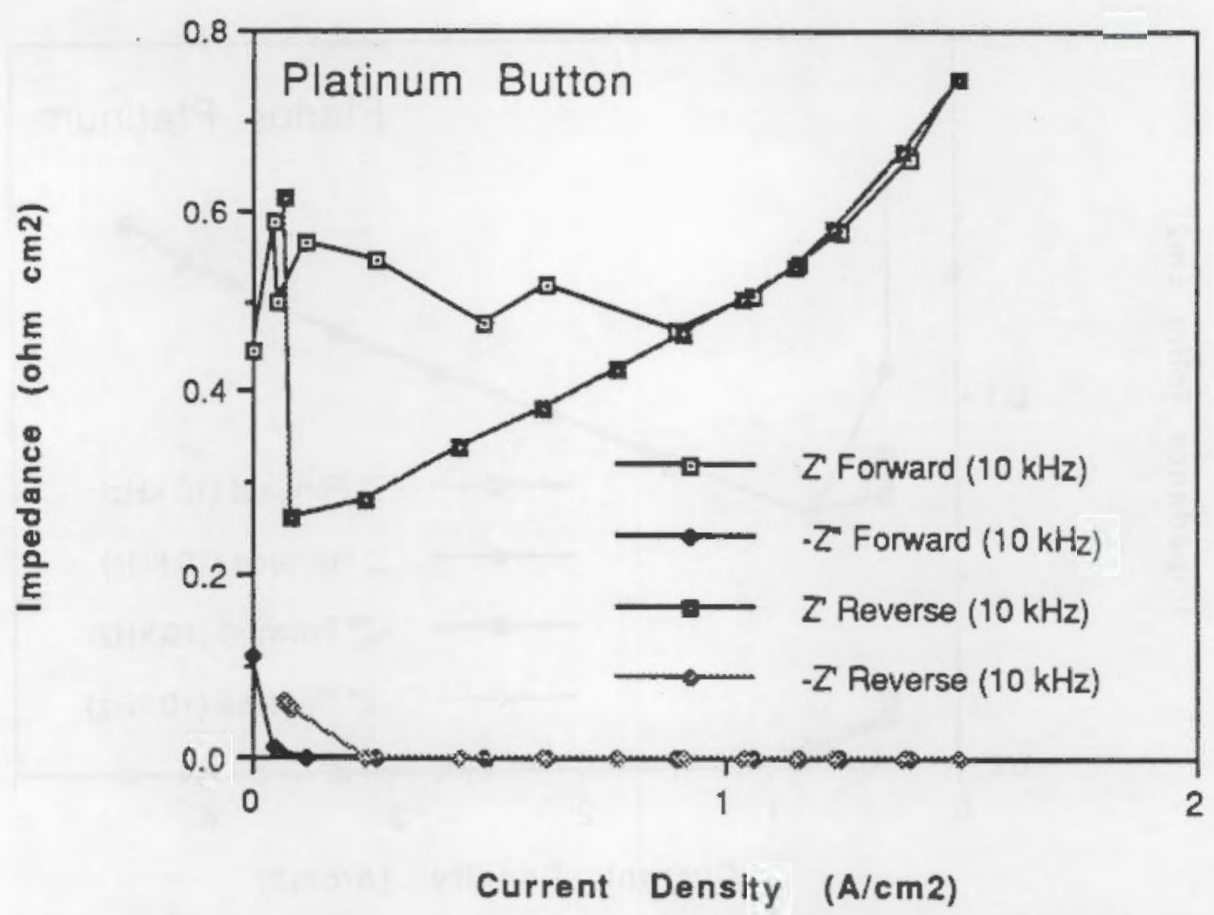

FIGURE 3.7. Impedance as a Function of Current Density for Platinum Button Anode

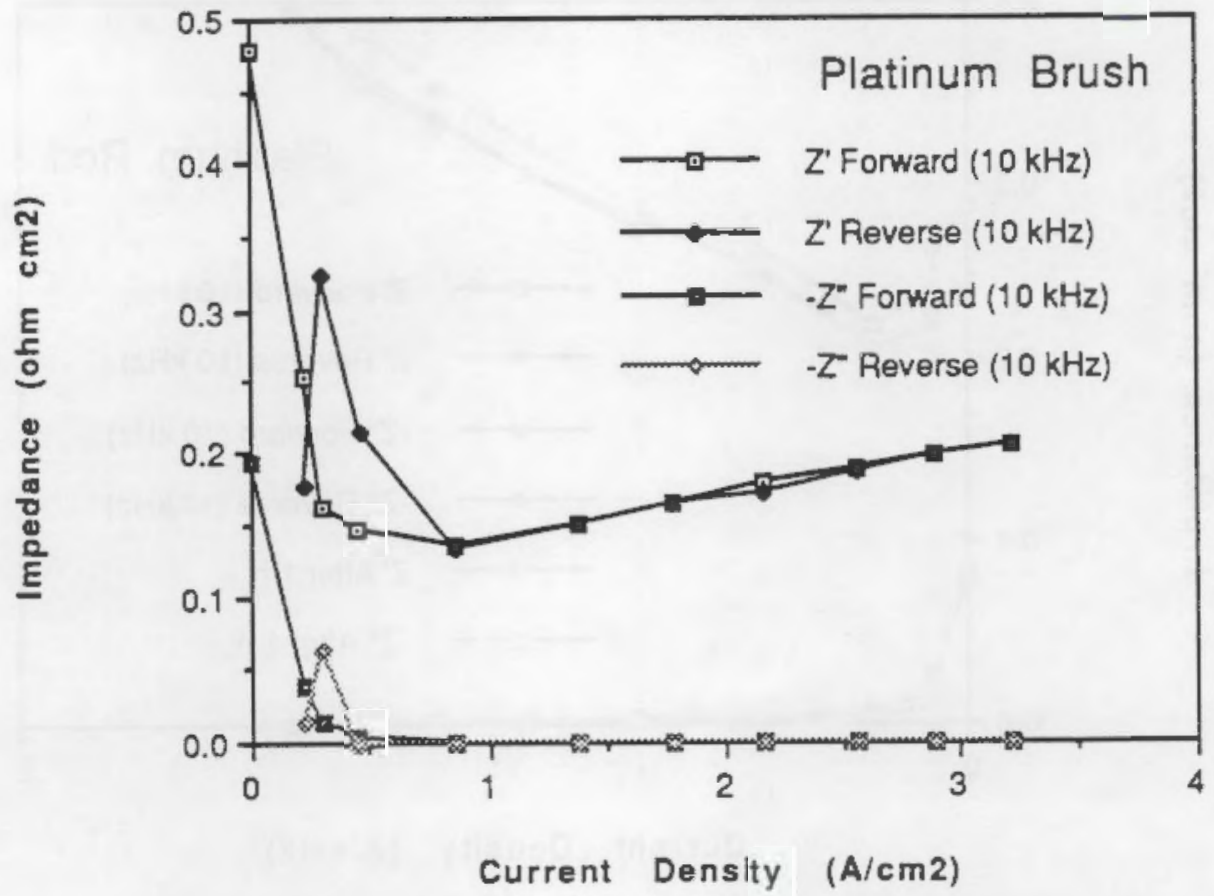

FIGURE 3.8. Impedance as a Function of Current Density for Platinum Brush Anode 
The planar platinum and platinum brush anodes showed inordinately low impedances as reflected in the different scales for Figures 3.5 and 3.8 . The reason is not certain, but it is not due to materials properties alone since the platinum rod and the platinum button gave impedances more in line with the cermet anodes. More likely, the much smaller surface areas for the planar platinum and platinum brush anodes (about an order of magnitude smaller than the other electrodes, as indicated in Table 2.1) and their placement at slightly different positions with respect to the reference electrode (as a consequence of their different size) contributed to the observed differences in measured impedances. Leakage of small amounts of electrolyte into the crevices between the anode and the BN sheath, while not causing a noticeable perturbation in the case of the large anodes, might have contributed significantly for the small-area anodes.

Thermal expansion of the anodes might have also caused a proportionately greater increase in exposed surface area for the smaller anodes. For example, in the case of the planar platinum electrode, assuming a heat zone of $4 \mathrm{in}$. at $1000^{\circ} \mathrm{C}$, thermal expansion would cause approximately a doubling in exposed surface area. These considerations suggest that the impedances and current densities for the small anodes may be in error because of an error in measuring the exposed surface area. The surprisingly large current densities in Figures 3.5 and 3.8 could also be explained by an error in the surface area measurements. Because of these differences, only electrodes with reasonably similar geometries could be compared reliably. The data for the fresh cermet anode were compared with that for the precorroded cermet anode. The data for the planar platinum anode were compared with that for the platinum brush anode. The platinum rod and platinum button anodes were compared specifically to determine the effects of anode shape on the electrochemical impedance.

Some hysteresis was also observed between the forward and reverse traces in a11 cases. The hysteresis was more significant for the cermet anodes, the platinum rod, and, particularly, the platinum button than for the planar $\mathrm{platinum}$ and platinum brush electrodes. To determine under what conditions hysteresis effects were minimal, impedance data were collected on the platinum rod after polarizing it anodicality at $1 \mathrm{~A} / \mathrm{cm}^{2}$ for $1 \mathrm{~h}$. As shown in 
Figure 3.6, these data were also slightly different from most of the data collected during the initial forward and reverse traces. However, at current densities around $0.5 \mathrm{~A} / \mathrm{cm}^{2}$, the data after $1 \mathrm{~h}$ were very close to data collected during the initial reverse trace. Data for $Z^{\prime}$ near $0.5 \mathrm{~A} / \mathrm{cm}^{2}$ and above taken from the reverse traces for the platinum rod and platinum button anodes are plotted in Figure 3.9. Similar data for the fresh and precorroded cermet anodes are plotted in Figure 3.10. Figure 3.11 shows a similar plot for the planar platinum and platinum brush anodes but over a much wider current density range. In all cases, the plots are very linear. Linear regression analyses were performed, and the results are given in the same figures. The correlation coefficients, R, were very close to 1.000 .

As shown in Figure 3.9, the platinum button anode has a much higher impedance than the platinum rod anode at $10 \mathrm{kHz}$ over the current density range plotted. Figure 3.10 shows that the precorroded cermet anode exhibited higher values for $Z^{\prime}$ than the fresh cermet anode over the current density range plotted, while Figure 3.11 indicates the platinum brush anode gave higher values for $Z^{\prime}$ than the planar platinum anode.

\subsection{VARIATION OF IMPEDANCE WITH TIME}

Figure 3.12 illustrates the variation of $Z^{\prime}$ (measured at $10 \mathrm{kHz}$ ) with time over the course of $6 \mathrm{~h}$ after a potential step to give a current density of $1 \mathrm{~A} / \mathrm{cm}^{2}$. The current density was maintained at this value by adjusting the polarization voltage. Data are shown for the fresh cermet anode, the precorroded cermet anode, and the platinum rod anode.

As shown in Figure 3.12, after an initial rise in impedance during the first few minutes, the impedance of the fresh cermet anode was fairly constant over the 6 -h period. A slight decrease may have begun after $5 \mathrm{~h}$, but it is not certain whether this trend is significant and persistent. In contrast, the precorroded cermet anode showed a steadily increasing impedance over the course of the $6 \mathrm{~h}$, almost doubling in value at the end of the test. The platinum rod anode showed very little variation with time similar to the fresh 


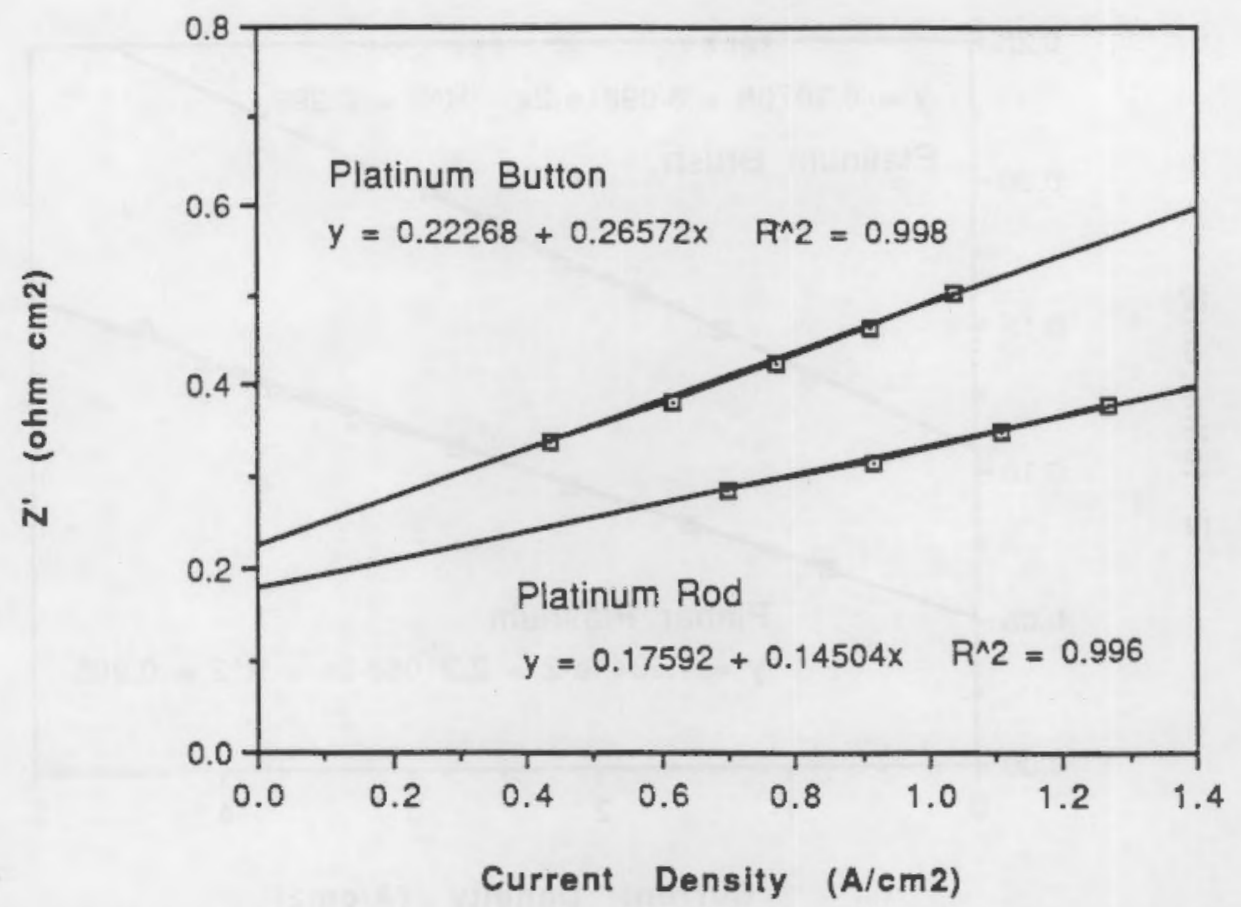

FIGURE 3.9. Linear Regions of $Z^{\prime}$ Versus Current Density Curves for Platinum Button and Platinum Rod Anodes

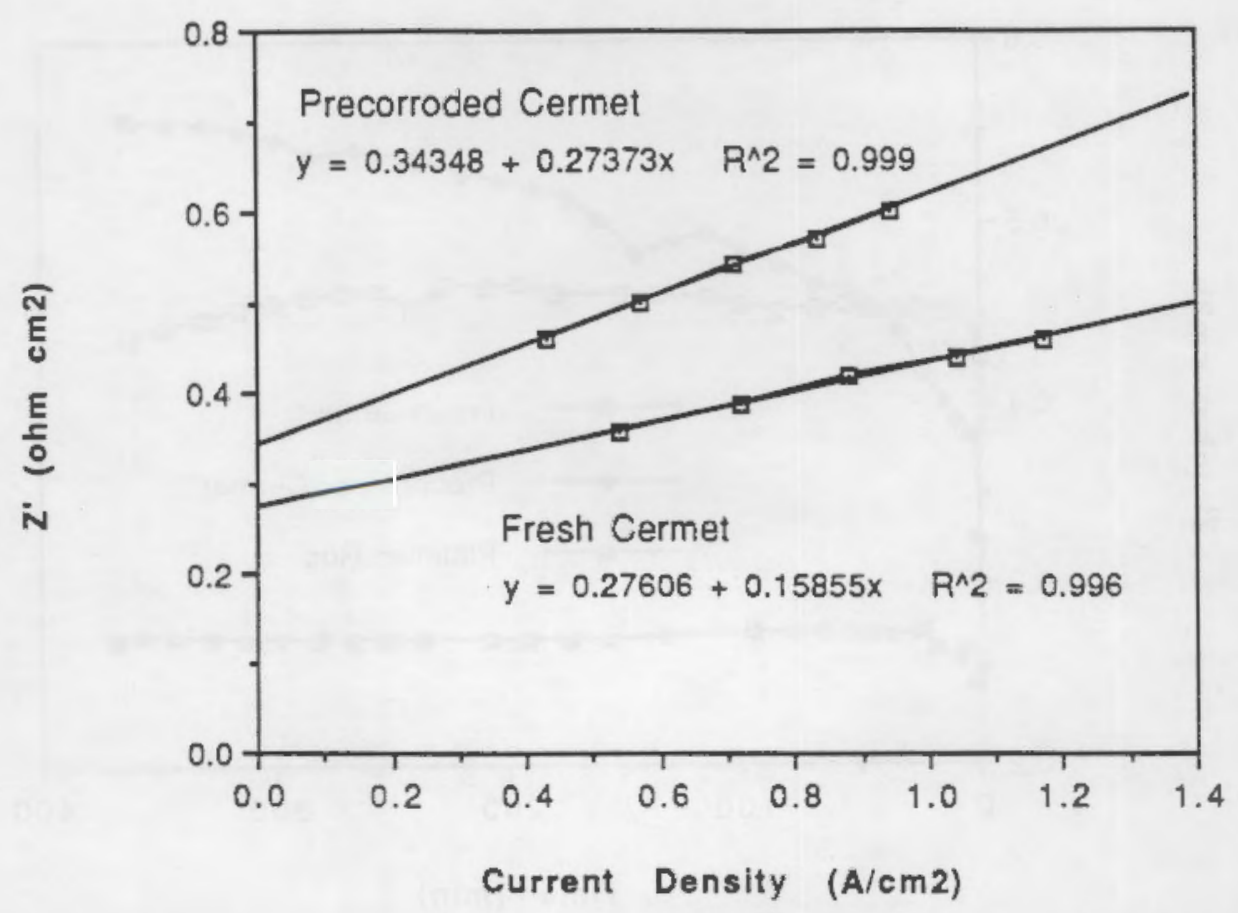

FIGURE 3.10. Linear Regions of $Z^{\prime}$ Versus Current Density Curves for Fresh Cermet and Precorroded Cermet Anodes 


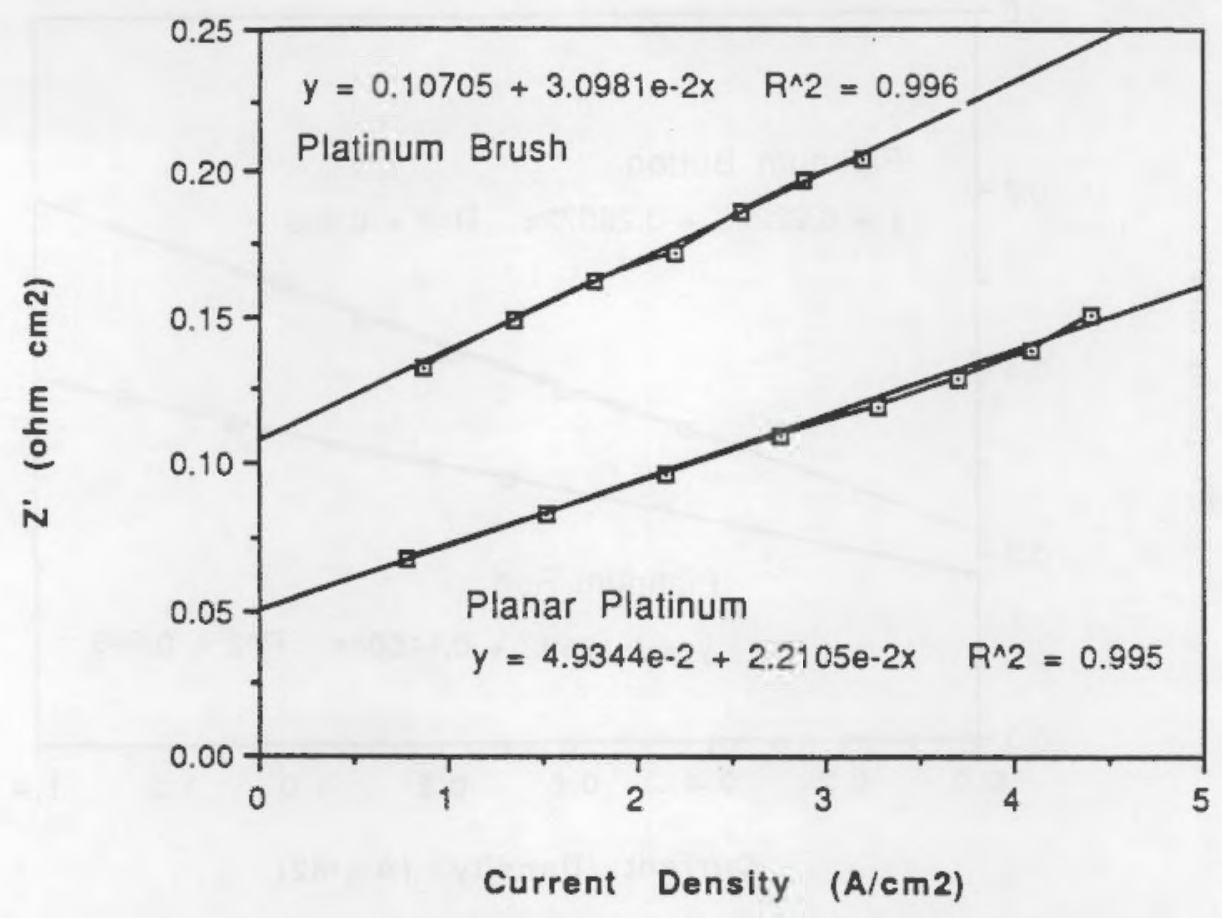

FIGURE 3.11. Linear Regions of $Z^{\prime}$ Versus Current Density Curves for Planar Platinum and Platinum Brush Anodes

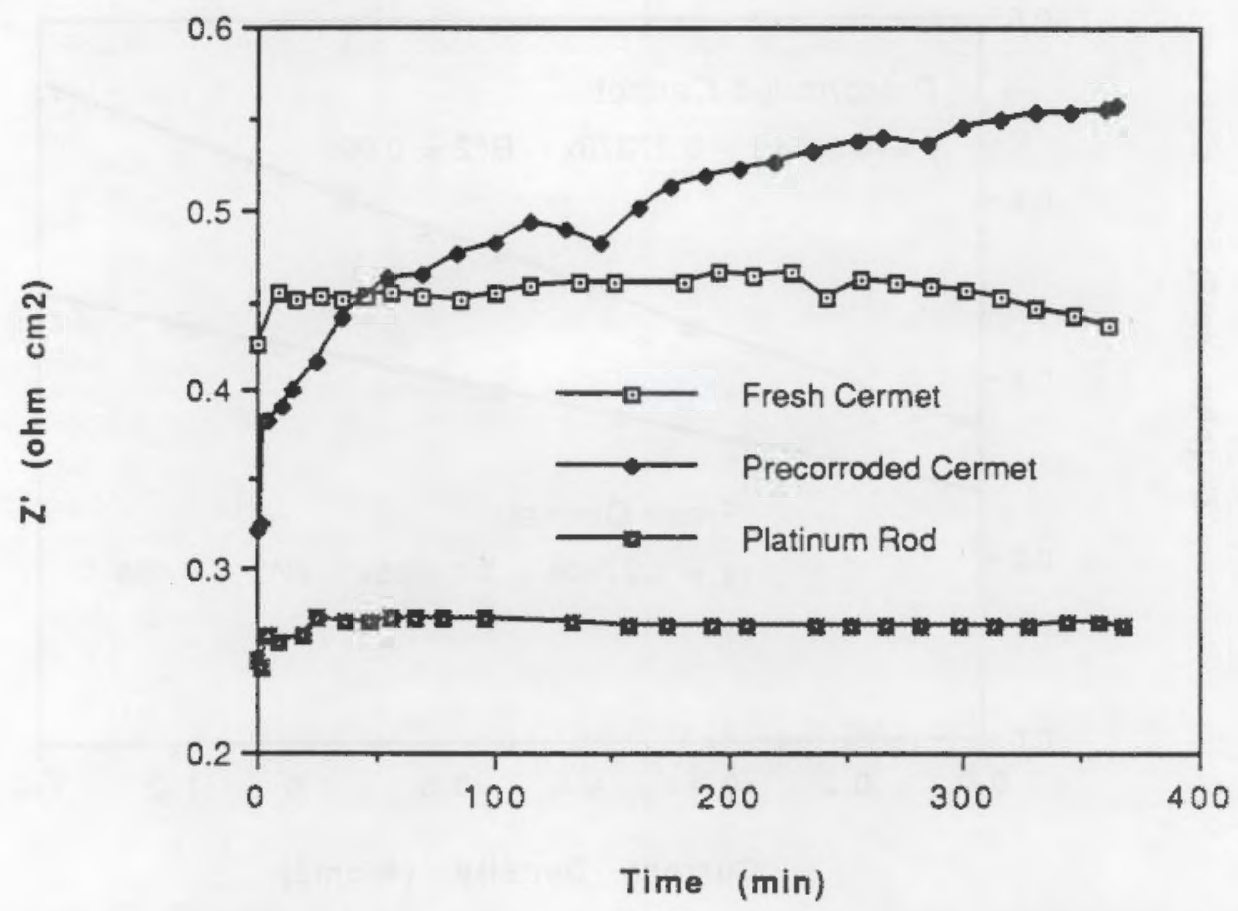

FIGURE 3.12. Variation of ' $Z^{\prime}$ with Time for Fresh Cermet, Precorroded Cermet and Platinum Rod Anodes 
cermet; although the absolute magnitude of the impedance was different, probably due to the different shapes of the anodes as discussed in Section 3.2. 



\subsection{DISCUSSION}

The source of the impedance on the cermet inert anodes was the principal issue under study. Using electrodes of different compositions and configurations, it was possible to determine the factors that contributed to the anode impedance. Unfortunately, the relative importance of each of these factors could not be distinguished since most of them are interrelated. The following approaches for analyzing the data were used: 1) comparing the impedances on the platinum rod and platinum button anodes; 2) characterizing the loops in the electrochemical impedance spectra; 3 ) comparing the differences in the impedance on fresh cermet anodes and precorroded cermet anodes with differences in impedance on the planar platinum anodes and platinum brush anodes, and observing how the impedance on the various anodes varied with time.

\subsection{EFFECT OF ANODE CONFIGURATION}

As shown in Figure 3.9, the impedance of the platinum anodes was strongly influenced by the anode configuration. The platinum button anode showed a higher impedance and a higher rate-of-change of impedance with current density (slope) than the platinum rod anode. Since these anodes were identical in composition (both platinum) and had the same surface finish, the differences in impedance behavior may be attributed to the differences in the configuration of the anodes. The two anodes were both cylindrical but had different amounts of horizontally oriented cross-sectional surface and different amounts of vertically oriented cylindrical sidewall exposed to the electrolyte. The platinum rod anode had predominantly sidewall or vertical area, while the platinum button anode had only cross-sectional or horizontal area.

Since the orientation of the surfaces has a strong influence on gas flow, it seems likely that the observed differences in the impedances for the platinum rod and the platinum button anodes arose from the differences in gas flow. A horizontal anode could trap more gas below it than a vertical anode where the gas flow would be relatively unimpeded. The trapped gas would be 
expected to increase the impedance of the anode by replacing a volume of electrolyte by an equivalent volume of more poorly conducting gas. As current density is increased, the amount of gas produced is increased and the impedance would also be expected to increase. This is exactly what was observed, as shown in Figure 3.9. The differences in impedance for the platinum anodes with different configurations suggest that gas bubbles are an important factor in determining the electrochemical impedance of inert anodes.

\subsection{COMPLEX IMPEDANCE SPECTRA}

The electrochemical impedance spectra provide additional evidence that an important component of the electrochemical impedance is from gas bubbles. $Z^{\prime}{ }_{1 f}$, the low-frequency intercept for these plots, is the sum of at least three components according to Figures 3.1 and 3.2. These components are $Z^{\prime}{ }_{h f}$, the "resistance" of the high-frequency process(es) that give(s) rise to the poorly defined high-frequency loop(s), and the "resistance" of the lowfrequency process giving rise to the low-frequency loop. The magnitude of the latter resistance is the diameter of the low-frequency loop.

$Z^{\prime}{ }_{h f}$ can be equated with the electrolyte resistance, $R_{e}$. The voltage drop through the electrolyte was computed for each anode as the product of the current density, $I$, and $R_{e}$. As shown in Table 4.1, the voltage drop through the electrolyte increased with current density for both the fresh cermet anode and the platinum rod anode.

TABLE 4.1. Impedances and Overvoltages for Anodes

\begin{tabular}{|c|c|c|c|c|c|c|}
\hline Anode & $\begin{array}{c}\text { Current (I), } \\
\mathrm{A} / \mathrm{cm}^{2} \\
\end{array}$ & $\begin{array}{l}Z^{\prime}{ }_{h f}, \\
\text { ohm cm } \\
\end{array}$ & $\begin{array}{c}Z^{\prime}{ }_{1 \mathrm{f}} \\
\mathrm{ohm} \mathrm{cm}^{2}\end{array}$ & $\begin{array}{l}I_{e}, \\
v \\
\end{array}$ & $\begin{array}{c}\text { Slope, } \\
V \\
\end{array}$ & $\begin{array}{l}\eta \\
V \\
\end{array}$ \\
\hline \multirow[t]{2}{*}{ Cermet } & 0.44 & 0.30 & 0.42 & 0.13 & 0.42 & 0.07 \\
\hline & 0.80 & 0.36 & 0.50 & 0.29 & 0.53 & 0.11 \\
\hline \multirow[t]{2}{*}{ Platinum } & 0.53 & 0.25 & 0.37 & 0.13 & 0.35 & 0.07 \\
\hline & 1.0 & 0.31 & 0.46 & 0.31 & 0.49 & 0.09 \\
\hline
\end{tabular}


Plots of $I_{\mathrm{e}}$ versus I for the platinum rod and fresh cermet anodes are shown in Figure 4.1. Additional $\mathrm{Z}^{\prime}$ data collected at $10 \mathrm{kHz}$ and at other current densities (and discussed in Section 3.2) are also included. The curves are non-linear almost certainly because of the increasing gas volume (from bubbles) at higher current densities. The variation of the voltage drop caused by changes in bubble configuration with current density at a given current density is therefore given by the local slope of the $I R_{e}$ versus I curve. This slope, which is listed in Table 4.1 for the platinum rod and fresh cermet anodes at the various current densities, is simply the additional resistance associated with the change in bubble configuration accompanying a small change in current density. As shown in Table 4.1, the value for the slope is very close to the magnitude of $Z^{\prime}{ }_{1 f}$ for each of the conditions studied. At a sufficiently low excitation frequency $(<1 \mathrm{~Hz})$, the spectra "capture" the effect of the bubble configuration on the overall impedance. The spectra-derived impedances also include contributions from the

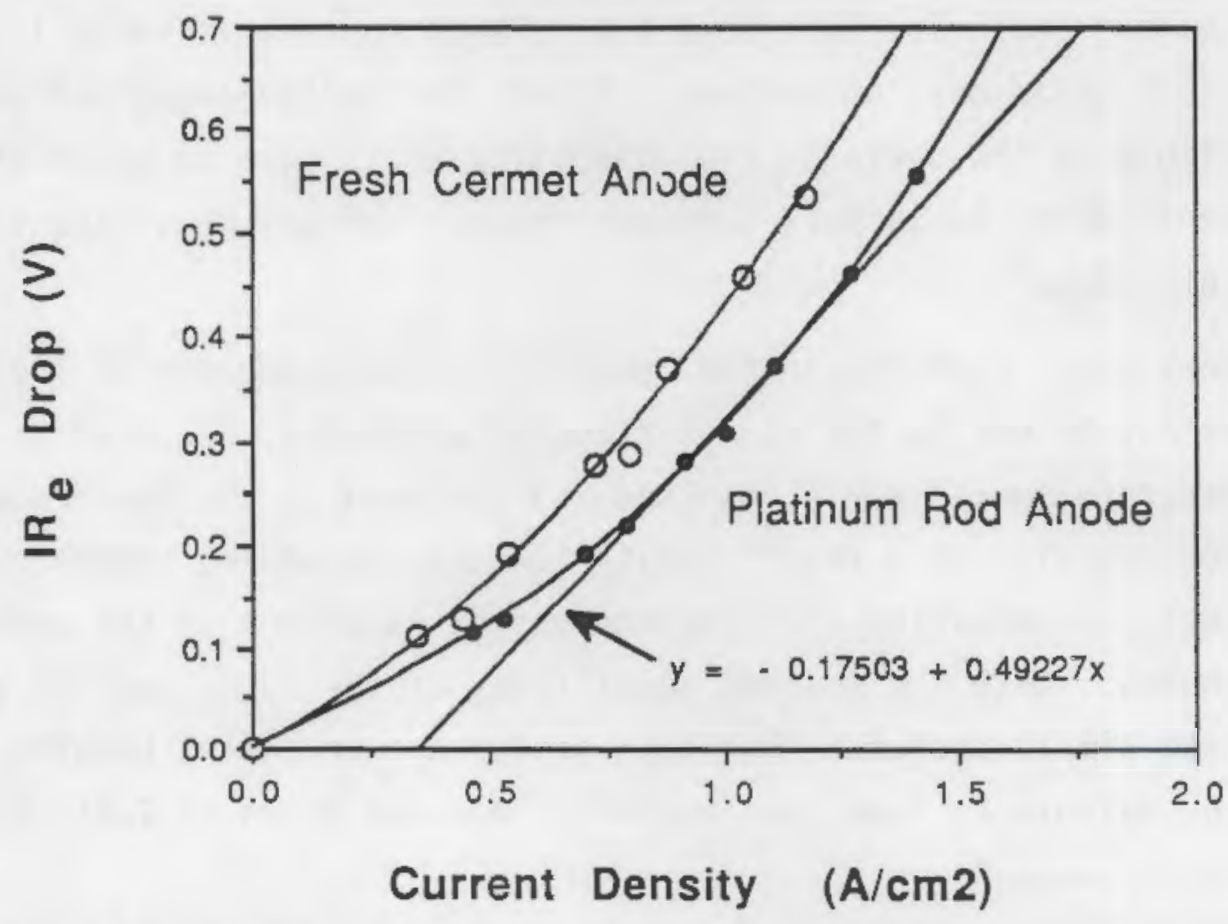

FIGURE 2.3. Variation of the Voltage Drop Through the Electrolyte with Current Density for the Fresh Cermet and Platinum Rod Anodes 
electrochemical transformations; but their effects are very sma11, especially at the higher current densities, as indicated by the size of the highfrequency features in Figures 3.1 and 3.2.

Given the important role the bubble configuration plays in determining the $Z_{1 f}$ and, consequently, the dc overpotential, the most likely source of the low-frequency loop is the bubbling process itself. At frequencies significantly above $1 \mathrm{~Hz}$, the bubble configuration is frozen; at frequencies significantly below $1 \mathrm{~Hz}$, the impedance contains an additional "bubble resistance." At intermediate frequencies, the bubble configuration lags behind the current and a loop is obtained.

Other assignments for the low-frequency loop seem implausible. The loop has a "capacitance" on the order of $10^{4} \mu \mathrm{F} / \mathrm{cm}^{2}$, which suggests it is not associated with a simple charge-transfer process. The apparent increase in diameter of the low-frequency loop with current density is also inconsistent with a simple Faradaic process, which predicts a resistance inversely proportional to current. The fact that the relaxation time is about $1 \mathrm{~s}$ also argues against an adsorption process. Given the limited amount of platinum atoms available on the surface, the adsorption would have to occur at a much faster rate in order to support the experimental current densities that are on the order of $1 \mathrm{~A} / \mathrm{cm}^{2}$.

The very small features in the complex impedance spectra at higher frequencies may be due to the charge-transfer processes, but this is uncertain since the features were poorly resolved and obscured by the low-frequency loop. Unfortunately, this result limits the utility of the electrochemical impedance data in comparing the electrochemical reactions at the cermet and platinum anodes. With the present sensitivity of the technique, it appears that the data simply indicate that both anodes are producing bubbles. Overvoltages, $\eta$, calculated from the impedance data and given in Table 4.1 , (a) $^{\text {are }}$

(a) The overvoltages were calculated by subtracting the voltage drop through the electrolyte, $I_{e}$, and the decomposition potential for alumina, $2.20 \mathrm{~V}$ versus $\mathrm{Al} / \mathrm{Al}_{2} \mathrm{O}_{3}$ (Grjotheim et al. 1982), from the observed anode potential relative to $\mathrm{Al}^{3} \mathrm{Al}_{2} \mathrm{O}_{3}$. 
also inconclusive. The values for the overvoltages on platinum differ significantly from those reported by Thonstad (1968) and, taken together with the observed differences in the $I_{e}$ versus $I$ curves for the $p l a t i n u m$ and cermet anodes (Figure 4.1), seem to indicate a dependence on cell geometry, anode shape and, possibly, anode surface structure (e.g., roughness). This would not be surprising since the magnitude of the "bubble effect" would also be expected to vary with these parameters. Studies on carbon anodes have shown similar effects (Dewing and van der Kouwe 1975). Given the need to keep power losses as low as possible in large-scale aluminum reduction cells, particularly in the case of inert anodes where the thermodynamic decomposition potential is high (relative to carbon anodes), further work would seem warranted to sort out the roles of these important variables on overvoltage.

\subsection{EFFECT OF ANODE SURFACE STRUCTURE}

The effects of surface structure are demonstrated in Figure 3.10 and 3.11. As shown in Figure 3.10, the impedances measured at current densities within the "linear region" are significantly higher for the precorroded cermet

anode than for the fresh cermet anode. For example, at $1.0 \mathrm{~A} / \mathrm{cm}^{2}$ the impedance is about 50\% larger for the precorroded cermet anode than for the fresh cermet anode. The slope of the curve also appears larger for the precorroded anode but whether this difference is significant or not is unclear from these data. Comparing the data for the fresh cermet anode in Figure 3.10 with the platinum button anode in Figure 3.9 shows good correlation of the magnitudes of the impedance measurements within this current density range but a slight difference in slope.

The larger impedances for the precorroded anode are consistent with results from other work at PNL (Windisch and Stice 1990b). From these earlier data it was concluded that the rougher, more porous surface structure of corroded anodes helped raise the impedance by somehow reducing the amount of active surface area. In light of the bubble effect proposed in Sections 4.1 and 4.2 , the role of roughness is better explained. A rougher surface area would retard the bubble flow and retain a higher volume of gas at the 
electrode surface. (The effect would be expected to be worse in the case of a horizontal electrode.) The larger gas volume would impart a higher solution resistance and, consequently, a larger $Z^{\prime}$ at high frequencies.

Despite these arguments, there is a possibility that the higher impedance for the precorroded anode was due to differences in the chemical composition of the surface region. The precorroded anode has a surface region depleted in copper metal and is possibly more resistive. As a way to address the possibility that a resistive reaction layer may have contributed to the impedance, platinum anodes with different configurations were tested. Figure 3.11 shows how the planar platinum anode compared with the platinum brush anode. As shown in Figure 3.11, the impedances were higher for the platinum brush anode than for the planar platinum anode. Since the platinum brush anode differed from the planar platinum anode because it had spaces (between bristles) that were intended to simulate pores, it is reasonable that these simulated pores contributed to the higher impedance.

Exactly how the pores gave rise to a higher impedance is uncertain, but gas bubbles may have been trapped in the spaces and this somehow retarded the flow of the gas across the anode surface. A reduction in the surface area alone (i.e. excluding pores) could not completely explain the differences in impedance since they were greater than $100 \%$ at some current densities. In comparison, the "nonpore" surface area for the brush electrode was on 1 y $20 \%$ less than that of the planar electrode as indicated in the Table 2.1 footnote. It is also significant that the impedances were greater for the brush anode than for the planar anode, which indicates that the pores themselves did not contribute additional surface area for electrolysis. Consequently, significant amounts of oxygen gas appear not to be generated in pores. Rather, the pores may act as traps for bubbles. The results suggest that the trapped gas not only removes active surface area from the process but impedes the reactions directly, perhaps by changing the dynamics of bubble flow at the electrode surface. Further work is clearly required to sort out the effects of a rough or porous surface on bubble dynamics. 
The variation of the impedances with time shown in Figure 3.12 for the fresh and precorroded cermet anodes and for the platinum rod anode al so suggests that the factors contributing to the impedance are mostly unchanging for the fresh cermet anode and quite dynamic in the case of the precorroded anode. The behavior of the fresh cermet anode is like platinum, relatively stable with time, suggesting the surface structure of the anode does not significantly change during polarization over the course of $6 \mathrm{~h}$. The increasing impedance of the precorroded anode, however, indicates that a cermet anode, once corroded, may worsen in performance. The effect may be due to an accelerated change in surface structure for the precorroded anode or to a very gradual saturation of the highly porous electrode surface by gas bubbles or electrolyte.

In summary, the impedance data suggest that the surface structure of the anode, i.e., roughness and/or surface porosity, plays an important role in determining the impedance during gas generation. The gas bubbles produced during electrolysis cause an increase in impedance as a function of current density, while the surface structure of the anode appears to influence the magnitude of this effect. 


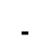

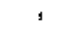




\subsection{CONCLUSIONS}

The electrochemical impedances of cermet inert anodes in aluminasaturated molten cryolite as a function of frequency, current density, and time indicated that a significant component of the impedance is due to the gas bubbles produced at the anode during electrolysis. Electrochemical impedance spectra exhibited a loop with a characteristic frequency of $1 \mathrm{~Hz}$ that was assigned to bubble relaxation. This assignment taken together with the variation of the electrolyte impedance with current density was very strong evidence that bubbles, and not a resistive film, were a primary source of the impedance under dc polarization conditions. Properties previous assigned to such a film are more likely due to the bubbles and those factors that affect the properties and dynamics of the bubbles at the anode surface. Varying the anode surface structure, i.e. porosity and orientation, was observed to influence the impedance and this was related to the effects of changing surface structure on bubble flow. 
- 


\subsection{REFERENCES}

Bard, A. J., and L. R. Faulkner. 1980. Electrochemical Methods: Fundamentals and Applications. John Wiley and Sons, Inc., New York.

Burgman, J. W., J. A. Leistra, and P. J. Sides. 1986. "Aluminum/Cryolite Reference Electrodes for Use in Cryolite-Based Melts." J. Electrochem. Soc. $133(3): 496-500$.

de Levie, R. 1964. "On Porous Electrodes in Electrolyte Solutions - IV." Electrochim. Acta. 9:1231-1245.

Dewing, E. W., and E. Th. van der Kouwe. 1975. "Anodic Phenomena in Cryolite-Alumina Melts: I. Overpotentials at Graphite and Baked Carbon Electrodes." J. Electrochem. Soc. 122(3):358-363.

Grjotheim, K., C. Krohn, M. Malinovsky, K. Matiasovsky, and J. Thonstad. 1982. Aluminum Electrolysis: Fundamentals of the Hall-Heroult Process. Aluminum-Verlag, Dusseldorf, Germany.

Strachan, D. M., O. H. Koski, S. C. Marschman, C. H. Schilling, and C. F. Windisch Jr. 1988. Fiscal Year 1987 Annual Report for the Inert Electrodes Program. PNL-6746, Pacific Northwest Laboratory, Richland, Washington.

Strachan, D. M., C. F. Windisch, Jr., O. H. Koski, L. G. Morgan, R. D. Peterson, N. E.Richards, and A. T. Tabereaus. 1990. Results from Electrolysis Test of a Prototype Inert Anode. PNL-7345, Pacific Northwest Laboratory, Richland, Washington.

Thonstad, J. 1968. "Anodic Overvoltage on Platinum in Cryolite-Alumina Melts." Electrochim. Acta. 13:449-456.

Tobias, C. W. 1959. "Effect of Gas Evolution on Current Distribution and Ohmic Resistance in Electrolyzers." ‥ Electrochem. Soc. 106(9):833-838.

Windisch, C. F., Jr., and N. D. Stice. 1990a. Characterization of the Reaction Layer or Film on PNL Inert Anodes: Progress Report for AprilDecember 1989. PNL-7326, Pacific Northwest Laboratory, Richland, Washington.

Windisch, C. F., Jr., and N. D. Stice. 1990b. Final Report on the Characterization of the Film on Inert Anodes. PNL-7589, Pacific Northwest Laboratory, Richland, Washington.

Zuka, S., C. Herdlicka, and M. Terzi. 1980. "On Porosity-Overvoltage Correlation for Carbon Anodes in Cryolite-Alumina Melts." Electrochim. Acta. $25: 211-216$. 


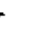

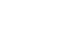

. 


\section{DISTRIBUTION}

No. of

Copies

\section{OFFSITE}

M. J. McMonigle

U.S. Department of Energy

Office of Industrial Programs

Forrestal Building

Washington, DC 20585

P. H. Salmon-Cox

U.S. Department of Energy

Office of Industrial Programs

Forrestal Building

Washington, DC 20585

12 DOE Office of Scientific and

Technical Information

C. Anderson

Columbia Aluminum Co.

85 John Day Dam Road

Goldendale, WA 98620

J. V. Anderson

WCVE3

EG\&G Idaho, Inc.

Idaho Falls, ID 83415

D. Auburg

Bonneville Power

Administration

P.0. Box 3621, PDX 97208

Portland, OR 97208

F. W. Baker

Ceramics Division

Alcoa Laboratories

Aicoa Center, PA 15069

M. Baltzell

Eastalco Aluminum Company

Alumax, Inc.

5601 Manor Woods

Frederick, MD 21701
No. of

Copies

J. A. Barclay

U.S. Bureau of Mines 2401 "E" Street N.W. Washington, DC 20241

H. Robert Baumgartner

Ceramics Division

Alcoa Laboratories

Alcoa Center, PA 15069

T. R. Beck

Electrochemical Technology Corp.

1601 Dexter Avenue

Seattle, WA 98109

S. Berwagan

Bonneville Power Administration

P.0. Box $3621 \mathrm{~K}$

Portland, OR 97208

T. M. Besmann

Metals and Ceramics Division

0ak Ridge National Laboratory

P.0. Box X, Bldg. 4515

Oak Ridge, TN 37831-6063

K. A. Blakely

President

Advanced Refractory

Technologies, Inc.

699 Hertel Ave.

Buffalo, NY 14207

M. H. Blenk

Du Pont

P.0. Box 787

Niagara Falls, NY 14302

L. G. Boxall

Martin Marietta Laboratories

1450 South Rolling

Baltimore, MD 21227 
No. of

Copies

J. Bracher

Kaiser Aluminum and Chemical Corp.

825 N.E. Multnomah St., Suite 960

Portland, OR 97232-2150

R. Brandt

Department of Materials Science and Engineering

University of Washington FB-10

Seattle, WA 98195

J. J. Brown, Jr.

Materials Engineering

Virginia Polytechnic Institute

Blacksburg, VA 24061

A. Budner

Bonneville Power

Administration

P.0. Box 3621--EPA

Portland, OR 97208

A. J. Caputo

Development Division

Oak Ridge $Y-12$ Plant

Building 9202 MS-8095

Oak Ridge, TN 37831-8095

N. Clark

Bonneville Power

Administration

Industrial Conservation

P.0. Box 3621

Portland, OR 97208

\section{A. Cooke}

Martin Marietta Laboratories

1450 South Rolling

Baltimore, MD 21227

J. A. Coppola

Standard 0il Engineered

Materials Company

P.0. Box 156

Niagara Falls, NY 14302
No. of

Copies

Business Expansion

Division Library

Washington State Dept of Trade

Business Expansion Library

20016 th Avenue $\# 2700$

Seattle, WA 98121-2522

R. Curtis

Materials Development

Corporation

81 Hicks Avenue

Medford, MA 02155

J. V. Day

Kaiser Aluminum and Chemical Corp

E2111 Hawthorne Road

Mead, WA 99021

D. H. DeYoung

Alcoa Technical Center

Alcoa Center, PA 15069

S. Diamond

Battelle Columbus Laboratories

505 King Avenue

Columbus, DH 43201-2693

C. W. Doerr

The Stackpole Corporation

Cermag Division

201 Stackpole Street

St. Marys, PA 15847

T. Dwonch

Snake River District

BPA

101 W. Poplar

Walla Walta, WA 99362

G. L. Ejtel

Stone \& Webster Engineering Corp.

Greenwood Plaza Box 5406

Denver, CO 80217 
No. of

Copies

R. Engdahl

Deposits and Composites, Inc.

318 Victory Drive

Herndon, VA 22070

J. F. El1iott

MIT

Room 4-138

77 Massachusetts Avenue

Cambridge, MA 02139

B. G. Epstein

A. D. Little, Inc.

955 Lenfant Plaza SW 4200

Washington, DC 20024-2119

J. W. Evans

University of California

Dept of Mat1. Sci. and Mineral Eng.

Berkeley, CA 94720

\section{R. A. Fenimore}

ICI Advanced Materials

Rollins Building, Eighth Floor

Wilmington, DE 19897

D. A. Figgins

ARCO Petroleum Products Co.

P.0. Box 61004

Anaheim, CA 92803-6104

P. Foster

Alcoa Laboratories

P.0. Box 772

New Kensington, PA 15068

J. Gee

Great Lakes Research Corp

P.0. Box 1031

Elizabethton, TN 37643

T. Gilligan

Eltech Systems Corp.

625 East Street

Fairport Harbor, $\mathrm{OH} \quad 44077$
No, of

Copies

H. M. Goldberger

Superior Graphite Co.

$120 \mathrm{~S}$. Riverside Plaza

Chicago, IL 60606

J. Goodwell

Center for Metals Production

Mellon Institute

4400 Fifth Avenue

Pittsburgh, PA 15213

J.A.S. Green

Martin Marietta Laboratories

1450 South Rolling

Baltimore, MD 21227

C. Griffin

Ceramatec Inc.

2425 S. 900 West

Salt Lake City, UT 84119

L. I. Grindstaff

Great Lakes Research Corp.

P.0. Box 1031

Elizabethon, TN 37643

J. Haggerty

MIT

Building 12, Room 009

77 Massachusetts Avenue

Cambridge, MA 02139

I. L. Harry

Electric Power Research Institute

P.0. Box 10412

Palo Alto, CA 94303

W. E. Haupin

2820 7th Street Road

Lower Burrel1, PA 15068

R. $\mathrm{Hi} 11$

Union Carbide Corp.

P.0. Box 94637

Cleveland, $\mathrm{OH} \quad 44101$ 
No. of

Copies

H. F. Hillegass

Aicoa Wenatchee Works

P.0. Box 221

Wenatchee, WA 98807

D. G. Howitt

College of Engineering

University of California, Davis

Davis, CA 95616

F. R. Huettig

Advanced Magnetics, Inc.

45 Corey Lane

Mendham, NJ 07945

G. R. Hyde

U.S. Bureau of Mines

2401 "E" Street N.W.

Washington, DC 20241

S. C. Jacobs

Primary Processing

Aluminum Company of America

ATcoa Technical Center

Alcoa Center, PA 15069

S. H. Jan

Tennessee Valley Authority

R\&D Division - MR 3A

Chattanooga, TN 37401

N. Jarrett

149 Jefferson Avenue

New Kinsington, PA 15068

J. Johnson

Intaì co Aluminum Company

P.0. Box 937

Ferndale, WA 98248

M. H. Johnson

Alcoa Wenatchee Works

P.0. Box 1031

Elizabethon, TN 37643
No. of

Copies

L. Joo

Great Lakes Research Corp

P.0. Box 1031

Elizabethon, TN 37643

M. Karmous

Oregon State Department of Energy

625 Marion Street, N.E.

Salem, OR 97310

R. Keller

RD 3 Roundtop Road

Export, PA 15632

K. Krupinski

Mail Stop 57

U.S. Steel Technical Center

] Technical Center Drive

Monroeville, PA 15146

G. Y. Lai

Cabot Corporation

P.O. Box 9013

Kokomo, IN 46902-9013

R. A. Landy

Director of Research

North American Refractories

Co.

3127 Research Dr.

State College, PA 16801

J. E. Lane

Ceramic Research and Development Center

Westinghouse Electric Corporation

1310 Beutah Road

Pittsburgh, PA 15235

Saj-Kwing Lau

Standard 0i1 Engineered Materia]s Company

Niagara Falls RaD Center

P.0. Box 832

Niagara Falls, NY 14302 
No. of

Copies

J. J. Leddy

Dow Chemical U.S.A.

1776 Building

Midland, MI 48640

W. W. Liang

Gas Research Institute

8600 West Bryne Mawr Avenue

Chicago, IL 60631

W. H. Link

Columbia Aluminum Corp.

85 John Day Dam Road

Gotdendale, WA 98620

Steve Loftness

Washington State Energy Office

$400 \mathrm{E}$. Union

Olympia, WA 98504

W. Long

Building B815

Dow Chemical

Freeport, Texas 77541

A. G. Longmuir

Kajser Aluminum and Chemical

Corp.

P.0. Box 877

Pleasonton, CA 94566

R. A. Lowden

Metals and Ceramics Division

Oak Ridge National Laboratory

P.0. Box X, B1dg, 4515

0ak Ridge, TN 37831-6063

W. N. Maclay

Koppers Company, Inc.

1005 William Pitt Way

Pittsburgh, PA 15238-1336

J. C. McCloskey

Ten Mile River Associates

$296 \mathrm{Mt}$. Hope Street

North Attleboro, MA 02760
No. of

Copies

S. C. Manaktala

Manager of Technology

Reduction Division

Kaiser Aluminum and Chemical

Corp

300 Lakeside Drive

0akland, CA 94643

V. H. Markant

Du Pont

P.0. Box 787

Niagara Fal1s, NY 14302

C. J. McMinn

Extractive Metallurgical Department

Reynolds Metals Company

P.0. Box 1200

Sheffield, AL 35660

C. H. McMurtry

Standard 0i1 Engineered

Materials Company

Niagara Falls R\&D Center

P.0. Box 832

Niagara Falls, NY 14302

M. A. Mitnick

Avco Specialty Materials

Subsidiary of Textron Inc.

2 Industrial Avenue

Lowe11, MA 01851

H. Mortensen

R. Palika

Cercom, Inc.

P.0. Box 70

Vista, CA 92083

B. C. Mutsuddy

Battelle Columbus Division

$505 \mathrm{King}$ Avenue

Columbus, $\mathrm{OH}$ 43201-2693 
No. of

Copies

P. Ness

Washington State Dept of Trade and Economic Development

20016 th Avenue $\$ 2600$

Seattle, WA 98121-2522

A. N. Patel

Battelle Columbus Laboratories

$505 \mathrm{King}$ Avenue

Columbus, $\mathrm{OH}$ 43201-2693

J. R. Payne

Kaiser ATuminum and Chemica] Corp.

P.0. Box 877

Pleasanton, CA 94566

T. Payne

Columbia Falls Aluminum $\mathrm{Co}$.

Columbia Falts, MT

W. Pebley

Oregon Freeze Dry Corp.

525 25th Avenue SW

P.0. Box 1048

Albany, OR 97321

K. Peterson

Columbia Aluminum Corp.

85 John Day Dam Road

Goldendale, WA 98620

R. D. Peterson

Reynolds Metals Company

P.0. Box 1200

Sheffield, AL 35660

T. R. Pritchett

Kaiser Aluminum and Chemica] Corp.

P.0. Box 877

Pleasanton, CA

W. W. Pritsky

Aluminum Association

900 19th St. N.W.

Washington, DC 20006
No. of

Copies

S. P. Ray

Alcoa Technical Center

Alcoa Center, PA 15069

J. F. Rhodes

Advanced Composite Materials Corp.

1525 S. Buncomb Rd.

Greer, SC 29651

N. E. Richards

Reduction Laboratory

Reynolds Aluminum Corporation

P. 0. Box 1200

Sheffield, AL 35660

J. J. Ritter

Ceramics Division

NationaT Bureau of Standards

Gaithersburg, MD 20899

R. C. Rohwedder

3028 Ohio Street

Longview, WAD. R. Sadoway

MIT

Room 8-109

77 Massachusetts Avenue

Cambridge, MA 02139

W. Scott

Department of Materiais

Science \& Engineering

Wilcox Hall FB-10

University of Washington

Seattle, WA 98195

D. R. Secrist

Great Lakes Research Corp.

P.0. Box 1031

Elizabethon, TN 37643

A. B. Shah

Noranda Aluminum, Inc.

P.0. Box 70

New Madras, MO 63869

Distr. 6 
No. of

Copies

N. Shelton

Intalco

1300 S. W. 5th, Suite 3508

Portland, OR 97201

Brian Spector

Pace Consultants

4848 Loop Central Drive

Houston, TX 77081

F. W. Spillers

Dow Chemical U.S.A.

B-1210 Building

Freeport, TX 77541

Dr. Richard M. Spriggs

Office of the Director

Center for Advanced

Ceramic Technology

Alfred University

Alfred, NY 14802

D. V. Stewart

Reynolds Metals Co.

P.0. Box 1200

Sheffield, AL 35660

D. Strahan

Reynolds Metals Company

P.0. Box 27003

Richmond, VA 23261

A. T. Tabereaux

Reynolds Metals Company

P.0. Box 1200

Sheffield, AL 35660

G. P. Tarcy

Aluminum Company of America

Alcoa Technical Center

Alcoa Center, PA 15069

P. Thaure

Primary Planning and

Production A] umax

400 S. El Camino Rd.

San Mateo, CA 94402
No. of

Copies

\author{
W. H. Thielbahr \\ Conservative Technology \\ Division \\ DOE-Idaho Operations office \\ 785 DOE Place \\ Idaho Falls, ID 83402
}

S. Thomson

General Manager

K1 ickitat PUD

$1313 \mathrm{~S}$. Columbus

Goldendale, WA 98620

R. Unger

Merner Research

P.0. Box 248

Ridgewood, NJ 07451A. Vinnard

Bonneville Power Administration (KWI)

P.0. Box 3621

Portland, OR 97208

T. Von Muller-KWI

Bonneville Power

Administration

P.0. Box 3621

Portland, OR 97208

D. H. Weinblatt

AIMCOR

One Parkway North

Deerfield, IL 60015

J. D. Weyand

EG\&G Idaho, Inc.

Idaho Falls, ID 83415

B. Wi]cox

Northwest Aluminum Co.

$3313 \mathrm{~W}$. Second St.

The Dalles, OR 97058

C. B. Wilson

Dow Chemicat U.S. A.

Texas Operations

$\mathrm{B}-101$ Building

Freeport, TX 77541 
No. of

Copies

J. C. Withers

Keramont Research Corporation

$4233 \mathrm{~S}$. Fremont Avenue

Tucson, AZ 85714

W. A. Zdaniewski

Engelhard Corporation

Men lo Park, CN 28

Edison, NJ 08818

\section{FOREIGN}

D. Brodie

Comalco Ltd.

55 Collins St.

Melbourne, AUSTRALIA

H. Connor

Group Licensing Controller

Johnson Matthey, plc

New Garden House

78 Hatton Garden

London ECIN 8JP ENGLAND

L. Dion

Alcan International Limited

C.P. 6090

Montreal, Quebec

CANADA, $\mathrm{H} 3 \mathrm{C} 3 \mathrm{H} 2$

T. Kjar

Comalco Ltd.

55 Collins St.

Melbourne, AUSTRALIA

E. W. Dewing

Alcan International

P.0. Box 8400

Kingston, Ontario

CANADA K7L $4 Z 4$
No. of

Copies

D. N. MacMillan

Alcan International

C.P. 1250

Jonquieve, Quebec

CANADA G7S $4 \mathrm{~K} 8$

J. H. Reimers

Jan H. Reimers and Associates Inc.

221 Lakeshore Road East

Oakville, Ontario

CANADA, L6J $\mathrm{lH} 7$

A. Oye

Institute of Inorganic Chemistry

Norwegian Institute of Technology

University of Trondheim

N-7034 Trondheim-NTH, NORWAY

J. Thonstad

Laboratories of Industrial Electrochemistry

Norwegian Institute of Technology

University of Trondheim

N-7034 Trondheim-NTH, NORHAY

K. 0. Vee

ASV Ardal Verk

N-5875 Ardalstargen, NORWAY

Dr. Eric Frazer

CSIRO Australia

Division of Mineral Products

$339 \mathrm{WiTliamstown} \mathrm{Road}$

P.0. Box 124

Port Me1bourne, Vic 3207 
No. of

Copies

ONSITE

DOE - Richland Operations

office

R. B. Goranson

25 Pacific Northwest Laboratory

M. Clement

N. C. Davis
No. of

Copies

D. K. Hilliard

G. L. McVay

N. L. Moore

L. G. Morgan (10)

C. H. Schilling

D. M. Strachan

R. E. Westerman

C. F. Windisch

Publishing Coordination

Technical Report Files (5) 


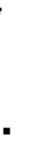

